\title{
A novel role for synaptic acetylcholinesterase as an apoptotic deoxyribonuclease
}

\author{
Aiying $\mathrm{Du}^{1, *}$, Jing Xie ${ }^{1, *}$, Kaijie Guo ${ }^{1}$, Lei Yang ${ }^{1}$, Yihan Wan ${ }^{1}$, Qi OuYang ${ }^{2}$, Xuejin Zhang ${ }^{1}$, Xin Niu ${ }^{1}$, \\ $\mathrm{Lu} \mathrm{Lu}{ }^{1}$, Jun $\mathrm{Wu}^{1}$, Xuejun Zhang ${ }^{1}$ \\ ${ }^{1}$ The State Key Laboratory of Cell Biology, Institute of Biochemistry and Cell Biology, Shanghai Institutes for Biological \\ Sciences, Chinese Academy of Sciences, Shanghai, China; ${ }^{2}$ Department of Pathology, School of Basic Medical Sciences, Fudan \\ University, Shanghai, China
}

In addition to terminating neurotransmission by hydrolyzing acetylcholine, synaptic acetylcholinesterase (AChE $\left.\mathrm{E}_{\mathrm{S}}\right)$ has been found to have a pro-apoptotic role. However, the underlying mechanism has rarely been investigated. Here, we report a nuclear translocation-dependent role for $\mathrm{AChE}_{\mathrm{S}}$ as an apoptotic deoxyribonuclease (DNase). $\mathrm{AChE}_{\mathrm{S}}$ polypeptide binds to and cleaves naked DNA at physiological $\mathrm{pH}$ in a $\mathrm{Ca}^{2+}-\mathrm{Mg}^{2+}$-dependent manner. It also cleaves chromosomal DNA both in pre-fixed and in apoptotic cells. In the presence of a pan-caspase inhibitor, the cleavage still occurred after nuclear translocation of $\mathrm{AChE}_{\mathrm{S}}$, implying that $\mathrm{AChE}_{\mathrm{S}}-\mathrm{DNase}$ acts in a $\mathrm{CAD}$ - and EndoG-independent manner. $A C h E$ gene knockout impairs apoptotic DNA cleavage; this impairment is rescued by overexpression of the wild-type but not (aa 32-138)-deleted $\mathrm{AChE}_{\mathrm{S}}$. Furthermore, in comparison with the nuclear-localized wild-type $\mathrm{AChE}_{\mathrm{S}}$, (aa 32-138)-deleted $\mathrm{AChE}_{\mathrm{S}}$ loses the capacity to initiate apoptosis. These observations confirm that $\mathrm{AChE}_{\mathrm{S}}$ mediates apoptosis via its DNase activity.

Keywords: synaptic acetylcholinesterase; nuclear translocation; DNA-binding protein; DNA cleavage;

deoxyribonuclease; apoptosis

Cell Discovery (2015) 1, 15002; doi:10.1038/celldisc.2015.2; published online 28 April 2015

\section{Introduction}

Synaptic acetylcholinesterase $\left(\mathrm{AChE}_{\mathrm{S}}\right)$, similar to the other two variants of $\mathrm{AChE}$ (erythrocytic AChE and read-through $\left.\mathrm{AChE}\left(\mathrm{AChE}_{\mathrm{R}}\right)\right)$, belongs to the type-B carboxylesterase/lipase family. The three different isoforms are encoded by a single gene, $A C h E$, but because of alternative splicing at the 3 ' region of acetylcholinesterase messenger RNA, the three variants differ in their carboxy-terminal sequences [1]. Erythrocytic AChE is expressed primarily in erythroid tissues, where it associates with membranes via the phosphoinositide moieties added posttranslationally. $\mathrm{AChE}_{\mathrm{R}}$ is expressed in embryonic and tumor cells, and is thought to be involved in the stress response and,

*These two authors contributed equally to this work. Correspondence: Xuejun Zhang

Tel: +086-21-54921403; Fax: +86-21-54921403

E-mail: xjzhang@sibcb.ac.cn or xjzhangxj@hotmail.com

Received 30 December 2014; accepted 27 January 2015 possibly, inflammation [2]. $\mathrm{AChE}_{\mathrm{S}}$ is the major form of acetylcholinesterase found in brain, muscle, and other tissues. The classical role of $\mathrm{AChE}_{\mathrm{S}}$ is to terminate neurotransmission by hydrolyzing acetylcholine at cholinergic synapses and neuromuscular junctions [3]. In addition, the enzyme has an important role in apoptosis of various types of cells. Studies in vitro and in vivo, have shown that $\mathrm{AChE}_{\mathrm{S}}$ is upregulated in response to various apoptotic stimuli and that apoptosis is attenuated by knockdown of its expression either by antisense RNA, small interfering RNA, or by heterozygous deletion of the $A C h E$ gene [4-6]. These results demonstrate a pro-apoptotic function of $\mathrm{AChE}_{\mathrm{S}}$, although the underlying mechanism remains to be elucidated.

Apoptosis is essential for many biological processes [7]. Distinct deoxyribonucleases (DNases) participate in apoptosis by catalyzing the hydrolytic cleavage of phosphodiester linkages in the DNA backbone. DNase $\mathrm{I}$ is the first enzyme to be recognized in mammalian cells to cleave nuclear DNA during apoptosis [8, 9]. 
However, DNase I-deficient JA3 cells are still capable of undergoing DNA fragmentation in response to treatment with an anti-Fas antibody [9]. This effect can be attributed to other DNases, such as the $40-\mathrm{kDa}$ DNA fragmentation factor (CAD/DFF40) and endonuclease G (EndoG).

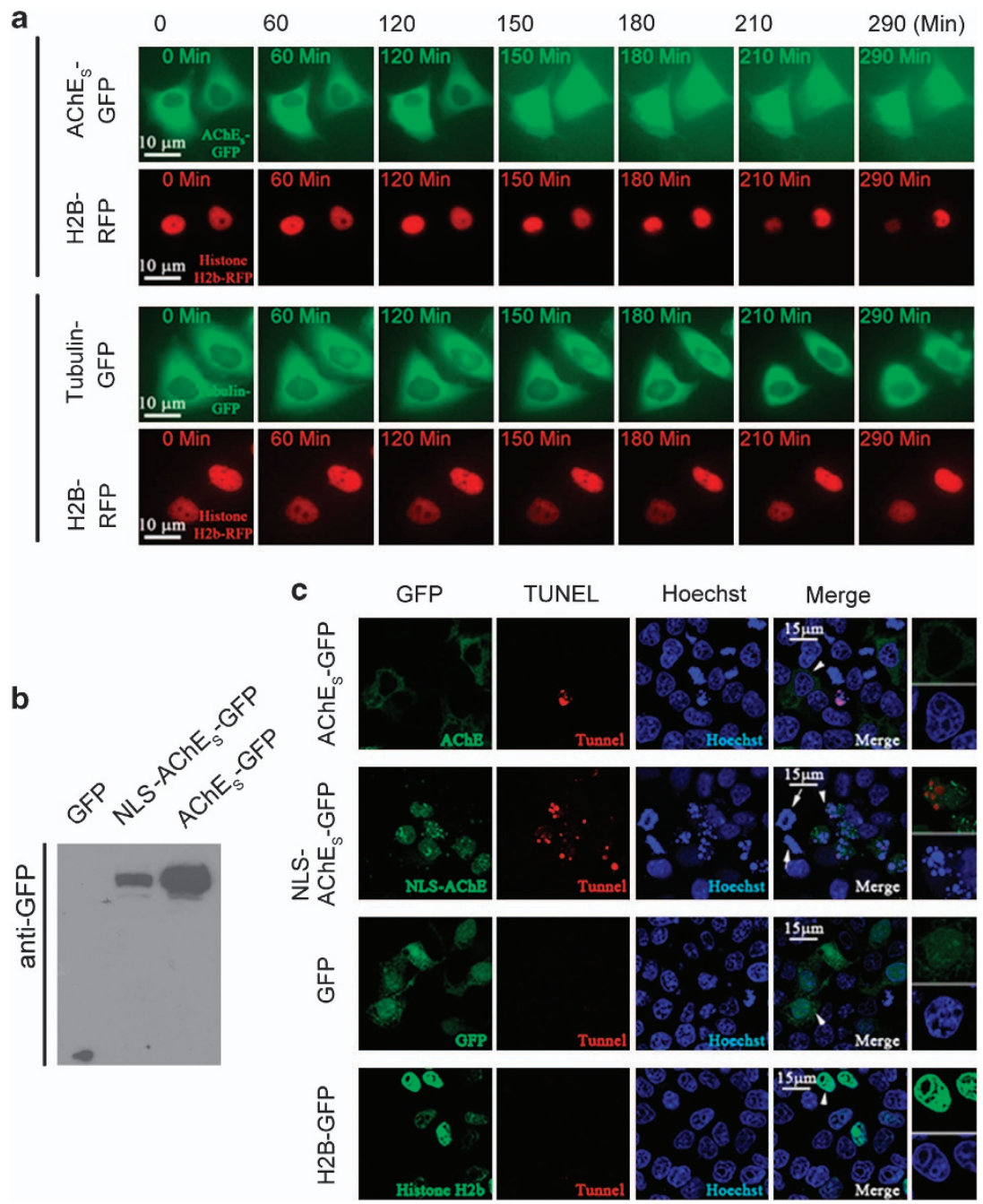

Figure 1 Synaptic acetylcholinesterase $\left(\mathrm{AChE}_{\mathrm{S}}\right)$ initiates apoptosis in the nuclear compartment. (a) Time-lapse images showing the alteration of the distribution of the indicated proteins during apoptosis. HeLa cells were transfected with the plasmids expressing the indicated fusion proteins. After $24 \mathrm{~h}$, cells were exposed to $100 \mu \mathrm{M} \mathrm{H}_{2} \mathrm{O}_{2}$ and time-lapse images were captured using a Leica AS MDW live cell image acquisition system. See also Supplementary Video S1a. (b) Western blot analysis of fusion protein expression. HeLa cells were transfected with the empty plasmid as a control or the indicated fusion protein expression plasmids. After $24 \mathrm{~h}$, cells were harvested. Whole-cell extracts were prepared, resolved by SDS-polyacrylamide gel electrophoresis, and blotted with anti-GFP antibody (Abmart, M20004). (c) Confocal images showing deoxynucleotidyl transferase (TdT)-mediated dUTP nick end labeling (TUNEL) staining in HeLa cells transfected with the plasmids expressing the indicated proteins. At $48 \mathrm{~h}$ after transfection, TUNEL assays were performed. Cells expressing green fluorescence protein (GFP) alone were used as the empty plasmid control, and those expressing histone H2B were used as the negative control. Scale bars, $15 \mu \mathrm{m}$. In the detailed image, the cells are indicated by an arrowhead (right panel; $\times 2$ magnification). (d) DNA ladder assay for apoptosis triggered by the indicated proteins overexpressed in HeLa cells for $48 \mathrm{~h}$. (e) Images showing the GFP-positive HeLa cells. At $18 \mathrm{~h}$ after transfection, GFP-positive HeLa cells were sorted by fluorescence-activated cell sorting. At $72 \mathrm{~h}$ after sorting, the images were taken using an inverted fluorescence microscope. Scale bar, $30 \mu \mathrm{m}$. (f) The viability curves of GFP-positive HeLa cells overexpressing the indicated proteins after sorting. The relative number of cells at the indicated time points was determined by the 3-(4,5-dimethylthiazol-2-yl)-2,5-diphenyltetrazoliumbromide (MTT) assay, with measurement of optical density (OD) at $570 \mathrm{~nm}$. The data are presented as the mean \pm s.d. of triplicate samples from one experiment that is a representative of three independent experiments. NLS, nuclear localization signal. 


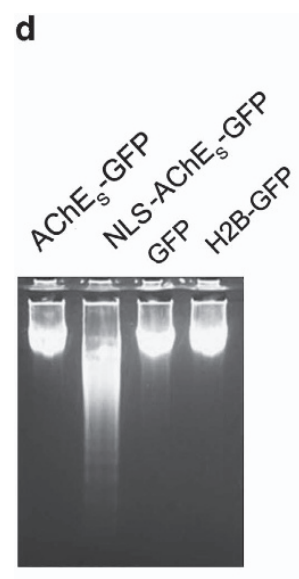

e
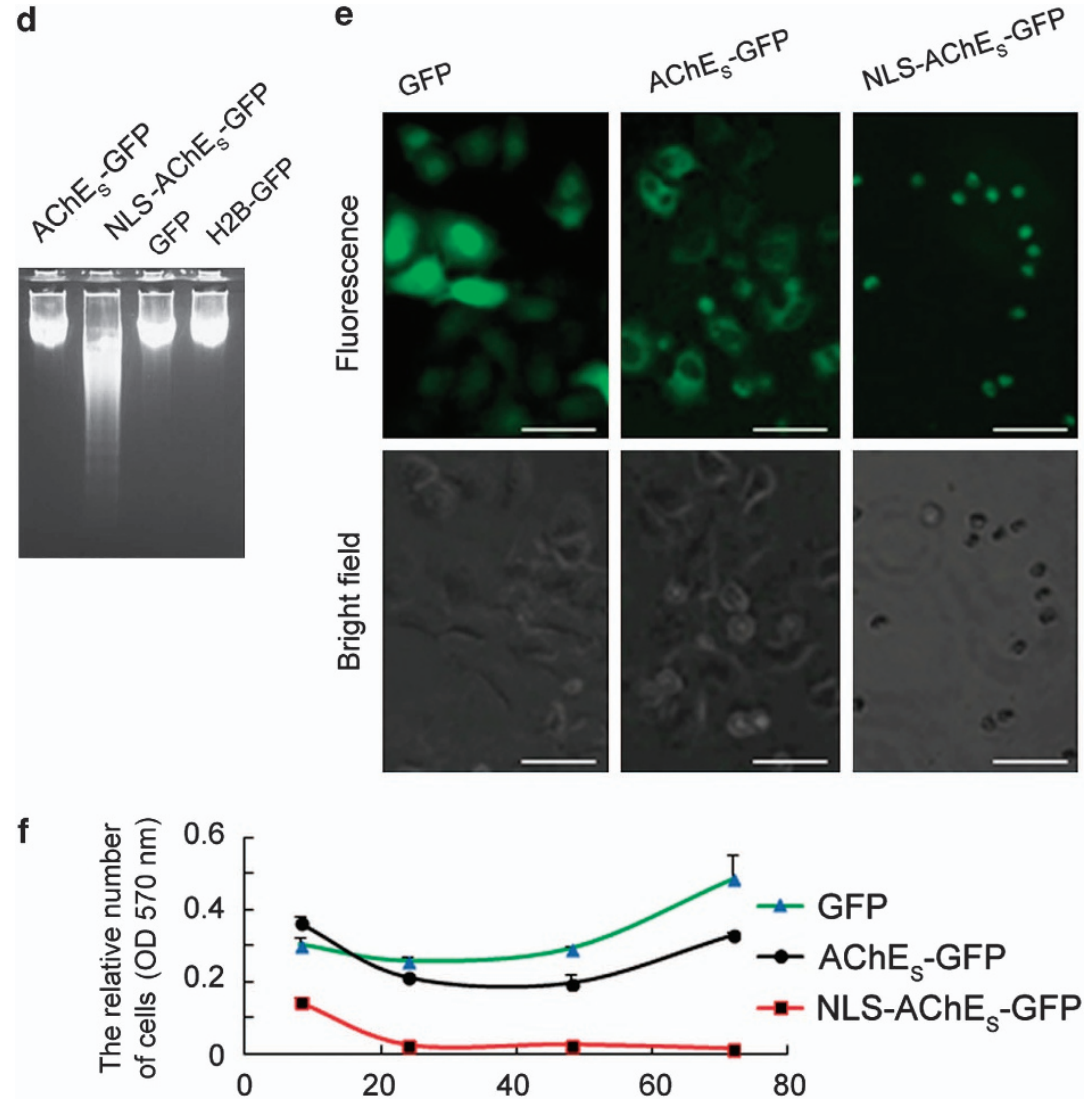

Figure 1 Continued.

$\mathrm{CAD} / \mathrm{DFF} 40$, the main effector involved in the apoptotic degradation of nuclear DNA into oligonucleosomal fragments, is a caspase-3-dependent DNase. After activated caspase-3-specifc cleavage of its inhibitor ICAD/DFF45, CAD/DFF40 is released from its heterodimeric complex and enters the nucleus to cleave DNA by introducing double-stranded breaks; in the absence of activated caspase-3, CAD/DFF40 was inactive and confined to the cytoplasm by binding with ICAD/DFF45 [10, 11].

EndoG, which is another caspase-dependent apoptotic DNase, is localized in the mitochondrion. After caspase activation in response to apoptotic insults, EndoG is released from mitochondria and translocates to the nucleus where it causes DNA degradation [12]. In DFF45-deficient cells, nuclear-translocated EndoG contributes to the residue of nucleosomal DNA fragments [12].

In the process of stepwise DNA degradation, CAD/ DFF40 and EndoG function at the early stage [10, 13], whereas DNase II functions at the later stage and is required for complete degradation of the fragments [14].
Among these well-known DNases, CAD/DFF40 is considered to account for the majority of the nuclease activity responsible for chromosomal DNA fragmentation [15, 16]. Although multiple DNases involved in chromatin DNA degradation have been reported, further DNases remain to be identified. Here, we report that $\mathrm{AChE}_{\mathrm{S}}$ mediates cell apoptosis by acting as a CAD- and EndoG-independent DNase.

\section{Results}

The nucleus is the optimal subcellular compartment for the pro-apoptotic function of $A C h E_{S}$

The subcellular localization of a protein is closely related to its function. Therefore, we first investigated alterations in the distribution of $\mathrm{AChE}_{\mathrm{S}}$ protein during apoptosis. When treated with hydrogen peroxide $\left(\mathrm{H}_{2} \mathrm{O}_{2}\right.$, one of the reactive oxygen species inducing oxidative stress), the cells underwent apoptosis, as shown by caspase-3 activation (Supplementary Figure S1A). In addition, upregulated AChE protein expression and its nuclear translocation were observed 


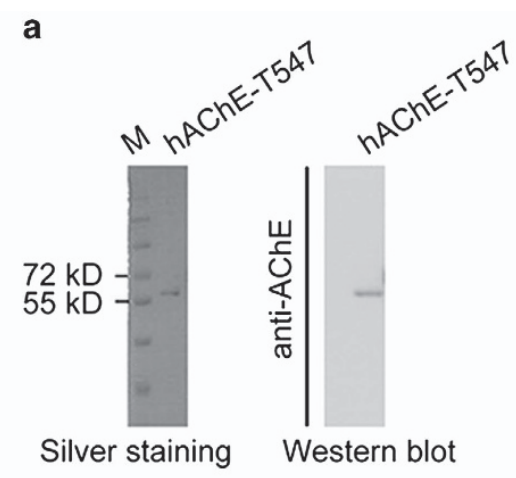

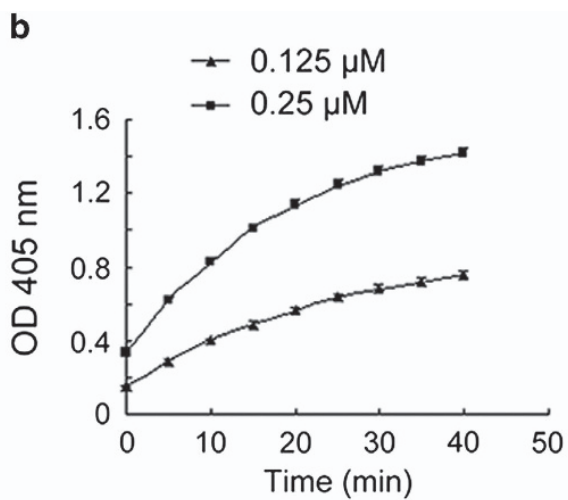
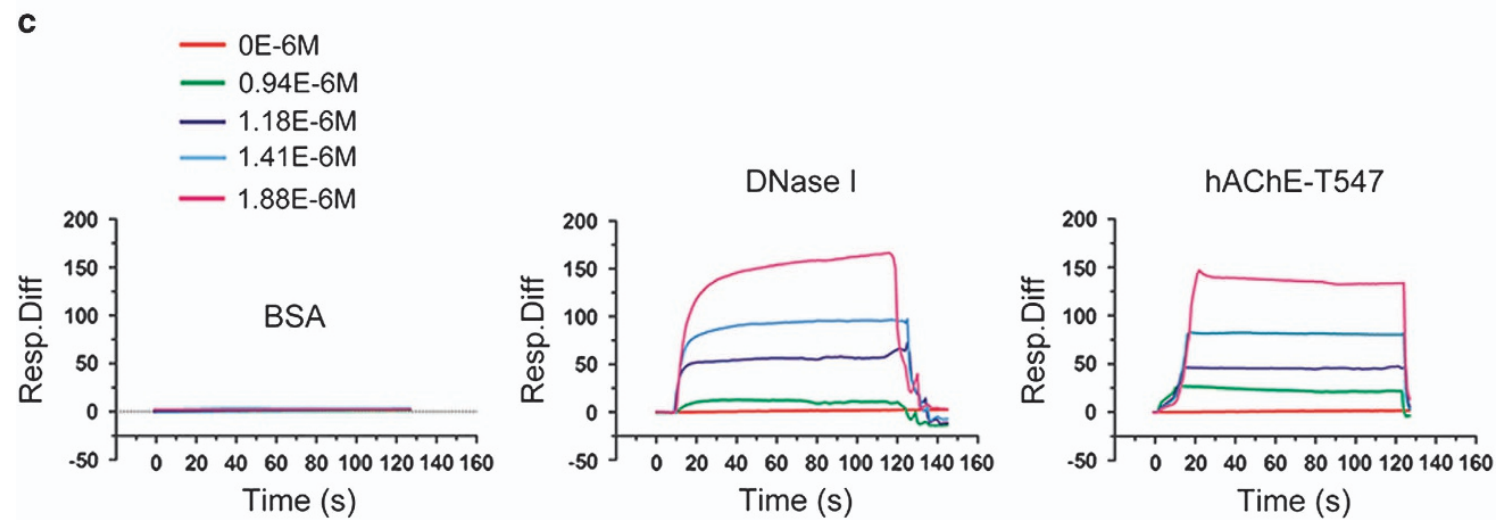

Figure 2 Interaction between synaptic acetylcholinesterase ( $\mathrm{AChE}_{\mathrm{S}}$ ) polypeptide with plasmid DNA. (a) Silver staining and western blot showing the purified human $\mathrm{AChE}_{\mathrm{S}}$ polypeptide, hAChE-T547. The anti-AChE antibody provided by Dr Palmer Taylor was used at a dilution of 1:1000. (b) Cholinesterase activity of hAChE-T547 examined by the Ellman assay, with measurement of optical density (OD) $405 \mathrm{~nm}$. Data shown represent one of three independent experiments. Values represent the mean \pm s.d. of triplicate samples. (c) The interaction between hAChE-T547 and pEGFP-c1 plasmid DNA examined by Biacore T100. DNase I and bovine serum albumin (BSA) were used as positive and negative controls, respectively. Data shown represent one of three independent experiments.

(Supplementary Figure S1). These data further support those obtained in our previous studies $[4,5]$. The AChE-specific antibody used in our study recognizes the common peptide fragments of all the three AChE variants. To investigate whether the variant $\mathrm{AChE}_{S}$ translocates into the nucleus in response to apoptotic stimuli, we constructed the $\mathrm{pEGFP}-\mathrm{AChE}_{\mathrm{S}}$ plasmid, encoding the $\mathrm{AChE}_{\mathrm{S}}$ protein fused with green fluorescence protein (GFP) at its $\mathrm{C}$ terminus. Time-lapse imaging showed that $\mathrm{AChE}_{\mathrm{S}}$ nuclear translocation closely accompanied the morphological changes during apoptosis induced by $\mathrm{H}_{2} \mathrm{O}_{2}(100 \mu \mathrm{M})$ in $\mathrm{HeLa}$ cells, suggesting that $\mathrm{AChE}_{\mathrm{S}}$ has a pro-apoptotic role in the nucleus (Figure 1a; Supplementary Video S1a).

To further confirm this suggestion, we constructed the pEGFP-NLS-AChE $E_{S}$ plasmid, encoding the $\mathrm{AChE}_{\mathrm{S}}$ protein fused with a nuclear localization signal (NLS) at its $\mathrm{N}$ terminus and GFP at its $\mathrm{C}$ terminus (Figure 1b). Overexpression of $\mathrm{NLS}-\mathrm{AChE}_{\mathrm{S}}-\mathrm{GFP}$ stimulated DNA breakage, which was examined by deoxynucleotidyl transferase (TdT)-mediated dUTP nick end labeling (TUNEL) (Figure 1c). In contrast, this effect was not stimulated by the overexpression of $\mathrm{AChE}_{\mathrm{S}}-\mathrm{GFP}$ without the NLS (Figures 1c and d). Furthermore, chromosomal DNA cleavage was detected as a DNA ladder pattern, a biochemical characteristic of apoptosis, by gel electrophoresis (Figure 1d), thus, demonstrating that the cell death induced by NLS-AChE $E_{S}$ overexpression occurred through apoptosis. Subsequently, 3-(4,5-dimethyl thiazol-2-yl)-2,5-diphenyltetrazoliumbromide (MTT) assays showed that although the GFP and $\mathrm{AChE}_{\mathrm{S}^{-}}$ GFP fusion protein hardly affected cell survival, NLS-AChE - -GFP stimulated gradual apoptosis (Figures 1e and f). These results demonstrate that $\mathrm{AChE}_{\mathrm{S}}$ promotes apoptosis only after translocation into the nucleus. The nucleus is the optimal subcellular compartment for the pro-apoptotic function of $\mathrm{AChE}_{\mathrm{S}}$. 


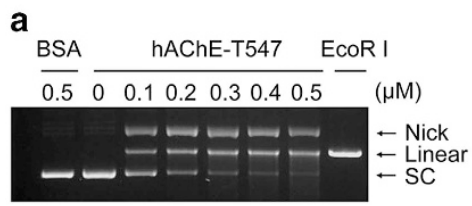

b

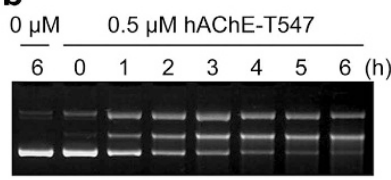

c d

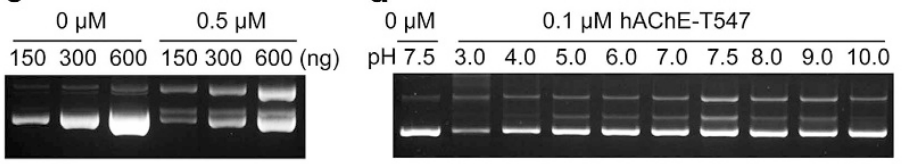

e

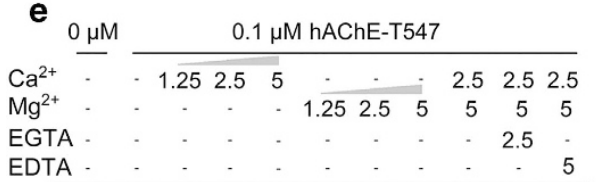

0 pM 3pM DNase I

- $2.52 .52 .5(\mathrm{mM})$

$5 \quad 5 \quad 5 \quad(\mathrm{mM})$
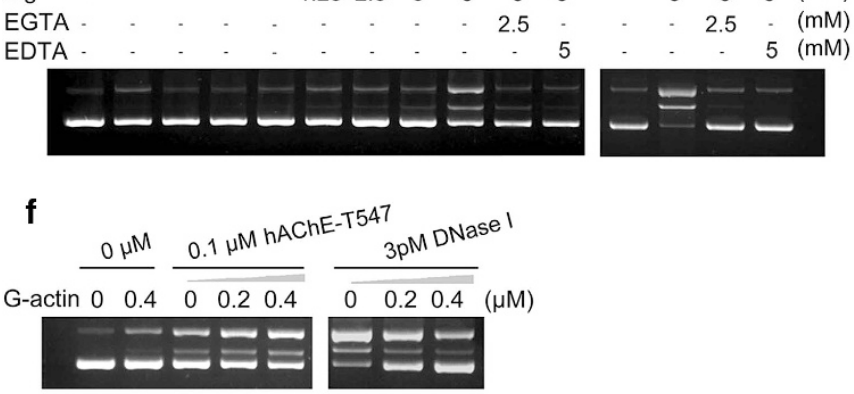

g

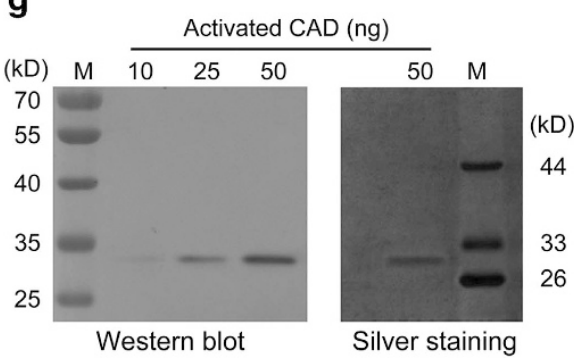

h
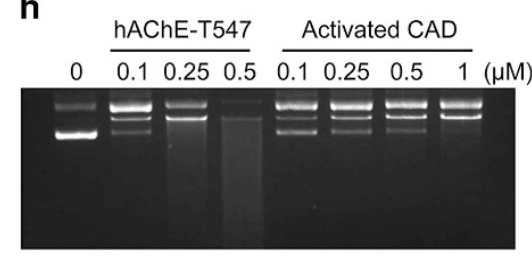

Figure 3 Purified synaptic acetylcholinesterase polypeptide cleaves DNA in a cell-free hydrolysis system. (a) Agarose gel images showing pEGFP-c1 plasmid DNA (150 ng) incubated with purified hAChE-T547 at the indicated concentration at $37^{\circ} \mathrm{C}$ for $6 \mathrm{~h}$. EcoRI-digested DNA $(0.5 \mathrm{U} / \mu \mathrm{l})$ was used to demarcate the linearized plasmid. Bovine serum albumin (BSA) was used as a negative

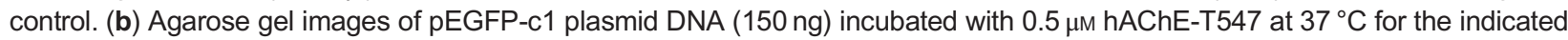
time periods. (c) Agarose gel images of pEGFP-c1 plasmid DNA (150-600 ng) incubated with or without $0.5 \mu \mathrm{m} \mathrm{hAChE-T547} \mathrm{at} 37^{\circ}$ $\mathrm{C}$ for $6 \mathrm{~h}$. (d) Agarose gel images showing pEGFP-c1 plasmid DNA (150 ng) incubated with $0.1 \mu \mathrm{m}$ hAChE-T547 at different pH at $37^{\circ} \mathrm{C}$ for $6 \mathrm{~h}$. (e) Effects of $\mathrm{Mg}^{2+}$ and (or) $\mathrm{Ca}^{2+}$ on DNA cleavage activity of hAChE-T547. The hydrolysis buffer containing Mg ${ }^{2+}$ and (or) $\mathrm{Ca}^{2+}$ at the indicated concentration was pre-incubated in the presence or absence of ethylene glycol tetraacetic acid (EGTA)/ EDTA at $37^{\circ} \mathrm{C}$ for $1 \mathrm{~h}$. hAChE-T547 and pEGFP-c1 plasmid DNA (150 ng) was then added and the incubation continued for a further $6 \mathrm{~h}$. DNase I was used as a positive control. (f) The effects of G-actin on DNA cleavage activity of hAChE-T547. hAChE-T547 and DNase I were pre-incubated with G-actin at the indicated concentration in the hydrolysis buffer at $37^{\circ} \mathrm{C}$ for $1 \mathrm{~h}$. $\mathrm{pEGFP-c1}$ plasmid DNA (150 ng) was then added and the incubation continued for a further $6 \mathrm{~h}$. DNase I was used as a positive control. (g) Silver staining and western blot showing the purified human caspase-activated deoxyribonuclease (CAD) (Arg87-Lys323; predicted molecular mass: $31.9 \mathrm{kDa}$ ) (USCN Life Science, Wuhan, China). The anti-CAD antibody (Merck Millipore, Darmstadt, Germany, AB16926) was used at a dilution of 1:500. (h) Agarose gel images showing pEGFP-c1 plasmid DNA (150 ng) incubated with purified hAChE-T547 and CAD/DFF40, respectively, at the indicated concentration at $37^{\circ} \mathrm{C}$ for $6 \mathrm{~h}$. SC, supercoiled.

The purified AChEs polypeptide binds to plasmid

$D N A$ in vitro

The intriguing question of why nucleus-localized $\mathrm{AChE}_{\mathrm{S}}$ triggers apoptosis remains to be answered.
In general, protein nuclear translocation in response to apoptotic stimuli is often associated with the modulation of nuclear components leading to chromatin DNA fragmentation (such as caspase-3) [17], or associated 

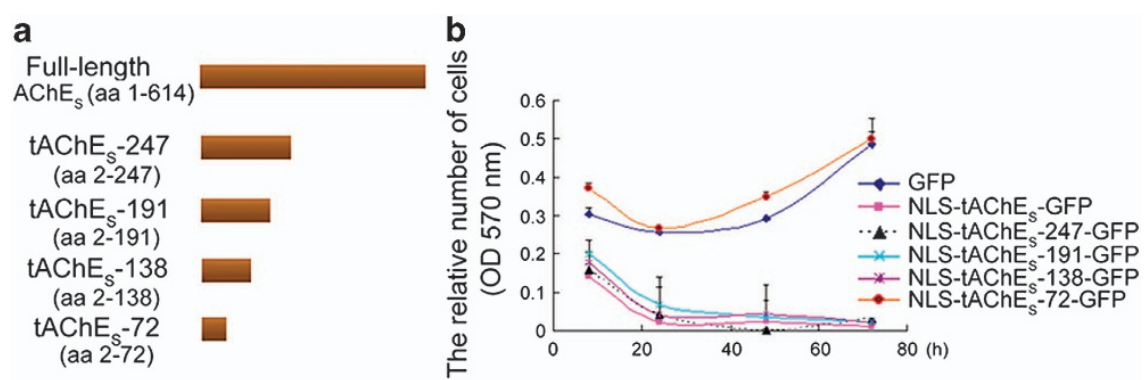

c

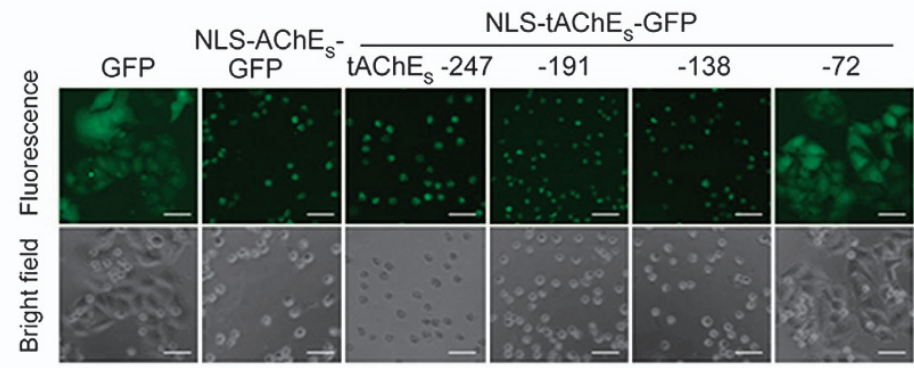

d

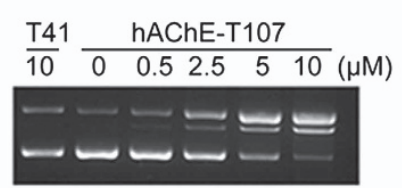

f

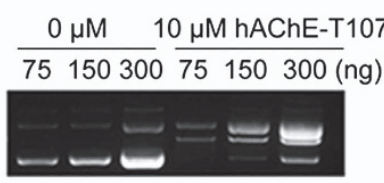

e
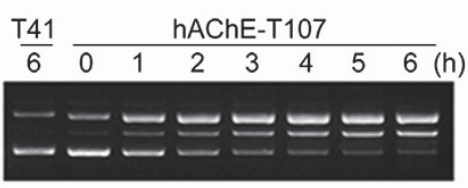

$\mathbf{g}_{0 \mu \mathrm{M}}$ $2.5 \mu \mathrm{M}$ hAChE-T107

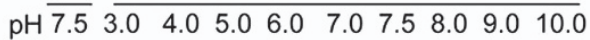

h

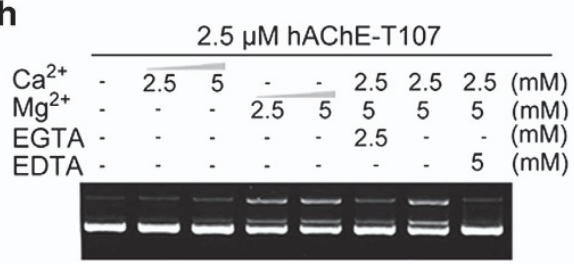

Figure 4 The $\mathrm{N}$ terminus of synaptic acetylcholinesterase $\left(A C h E_{S}\right)$ exhibits the pro-apoptotic and DNA cleavage functions. (a) A schematic diagram of human $\mathrm{AChE}_{S}$ and the truncated $\mathrm{AChE}_{S}\left(\mathrm{t} A \mathrm{ChE}_{\mathrm{S}}\right.$ ) with distinct $\mathrm{C}$ termini. (b) The viability curves of green fluorescence protein (GFP)-positive HeLa cells overexpressing the indicated proteins during $72 \mathrm{~h}$ after sorting. The relative number of cells at the indicated time points was determined by the 3-(4,5-dimethylthiazol-2-yl)-2,5-diphenyltetrazoliumbromide assay. The data are presented as the mean \pm s.d. of triplicate samples from one representative of three independent experiments. (c) Images obtained using inverted phase-contrast microscopy showing GFP-positive HeLa cells at $72 \mathrm{~h}$ after sorting. Scale bar, $30 \mu \mathrm{m}$. (d) Agarose gel images showing pEGFP-c1 plasmid DNA (150 ng) incubated with the synthesized hAChE-T107 at the indicated concentration at $37^{\circ} \mathrm{C}$ for $6 \mathrm{~h}$. (e) Agarose gel images of pEGFP-c1 plasmid DNA (150 ng) incubated with $10 \mu \mathrm{m} \mathrm{hAChE-T107}$ at $37^{\circ} \mathrm{C}$ for the indicated time periods. (f) Agarose gel images of pEGFP-c1 plasmid DNA (75-300 ng) incubated with or without $10 \mu \mathrm{m}$ hAChE-T107 at $37^{\circ} \mathrm{C}$ for $6 \mathrm{~h}$. (g) Agarose gel images of pEGFP-c1 plasmid DNA $(150 \mathrm{ng})$ incubated with $2.5 \mu \mathrm{m} \mathrm{hAChE-T107}$ at different $\mathrm{pH}$ at $37^{\circ} \mathrm{C}$ for $6 \mathrm{~h}$. (h) Effects of $\mathrm{Mg}^{2+}$ and (or) Ca $\mathrm{Ca}^{2+}$ on DNA cleavage activity of hAChE-T107. The assay protocol was similar to that described in Figure 3e, except that $2.5 \mu \mathrm{m}$ hAChE-T107 was added and the incubation continued for $8 \mathrm{~h}$. EGTA, ethylene glycol tetraacetic acid; NLS, nuclear localization signal; OD, optical density.

with chromatin DNA cleavage (such as CAD/DFF40 and EndoG) $[11,18]$. We aimed to determine whether $\mathrm{AChE}_{\mathrm{S}}$ hydrolyzes DNA.
First, the DNA-binding capacity of $\mathrm{AChE}_{\mathrm{S}}$ was examined. The amino-acid (aa) 1-574 region is shared by all three variants of human AChE, and aa $36-574$ is 
the putative region used to investigate the acetylcholine esterase activity of AChE and its crystalline structure [19]. Therefore, human $\mathrm{AChE}_{\mathrm{S}}$ aa 32-578 (hAChET547) was overexpressed and purified (Figure 2a). As expected, the Ellman assay showed that hAChET547 exhibited acetylcholine-hydrolyzing activity (Figure 2b). Importantly, similar to DNase I, hAChET547 bound plasmid DNA, although bovine serum albumin (Sigma) did not (Figure 2c). Accurate measurement of the dissociation constant $(\mathrm{Kd})$ was rendered impractical because the plasmid solutions in the mobile phase became too 'sticky' to be injected onto the chip at concentrations higher than $1.88 \times 10^{-6} \mathrm{M}$. Nevertheless, the data indicated the binding of hAChET547 to DNA, which prompted us to determine the capacity of $\mathrm{AChE}_{\mathrm{S}}$ to digest DNA.

The purified human $A C h E_{S}$ polypeptide cleaves naked $D N A$ at physiological $\mathrm{pH}$ in a $\mathrm{Ca}^{2+}-\mathrm{Mg}^{2+}$-dependent manner

After incubation with pEGFP-c1 plasmid DNA in hydrolysis buffer $(5.0 \mathrm{~mm}$ Tris- $\mathrm{HCl}, \mathrm{pH} 7.5 ; 2.5 \mathrm{~mm}$ $\mathrm{CaCl}_{2} ; 5.0 \mathrm{~mm} \mathrm{MgCl}_{2}$ ) at $37^{\circ} \mathrm{C}$ for $6 \mathrm{~h}$, hAChE-T547 converted the supercoiled DNA to the nicked and linear forms in a dose- and time-dependent manner (Figures $3 \mathrm{a}$ and $\mathrm{b}$ ). The cleavage pattern of plasmid DNA was the same as that resulting from cleavage by CAD/DFF40 [20], EndoG [21], DNase I [22], and tDCR-1 (a functional analog of DFF40 in Caenorhabditis elegans) [10]. As expected, the amount of the products correlated directly with the amount of the substrate plasmids (Figure 3c). Furthermore, the optimal $\mathrm{pH}$ for cleavage by the peptide was found to be 7.5 (Figure 3d), similar to those of CAD/DFF40 [23]. EndoG [21], DNase I [24], DNase $\gamma$ [25], and tDCR-1 [10].

Apoptotic DNases are usually activated by divalent metal ions [26]. hAChE-T547 showed very weak DNA cleavage activity in the presence of $\mathrm{Mg}^{2+}(1.25-5 \mathrm{~mm})$ alone, and the cleavage was hardly detected in the presence of $\mathrm{Ca}^{2+}(1.25-5 \mathrm{~mm})$ only (Figure 3e). However, the combination of $\mathrm{Mg}^{2+}$ and $\mathrm{Ca}^{2+}$ showed an obvious co-activating effect on the enzyme, which was further confirmed by the observation that either the $\mathrm{Ca}^{2+}$-chelator ethylene glycol tetraacetic acid or the versatile chelating agent EDTA markedly inhibited the cleavage (Figure 3e). These data indicated a $\mathrm{Ca}^{2+}-\mathrm{Mg}^{2+}$-dependent DNA cleavage activity of $\mathrm{AChE}_{\mathrm{S}}$.

Human AChE-T547 was overexpressed in HEK 293S stable cells, secreted into and purified from the cell culture medium. It is noteworthy that DNase I is also a secreted protein detected in most body fluids, including serum $[27,28]$. In spite of this, G-actin, a specific inhibitor of DNase I, inhibited DNA cleavage activity of DNase I but not that of hAChE-T547 (Figure 3f). Thus, the DNA degradation was not induced by contaminating DNase I.

Despite this, $\mathrm{AChE}_{\mathrm{S}}-\mathrm{DNase}$ activity was relatively low compared with that of DNase I (Figures 3e and $\mathrm{f}$ ), which is ubiquitously expressed in mammalian tissues. However, the enzyme (Sigma) used in our work was obtained from bovine pancreas, the most efficient DNase, which mainly is a digestive enzyme. In view of this, it is not surprising that $\mathrm{AChE}_{\mathrm{S}}-\mathrm{DNase}$ activity is much lower than that of DNase I. To further determine whether it is normal for an apoptotic DNase to show such low activity as that of $\mathrm{AChE}_{\mathrm{S}}-\mathrm{DNase}$, we compared the DNA degradation capacity of AChE-T547 and CAD. The purified human CAD polypeptide (Arg87-Lys323; predicted molecular mass $31.9 \mathrm{kDa}$ ), was purchased from USCN Life Science, China. Silverstained gels showed a band with a molecular weight between 26 and $33 \mathrm{kDa}$, which was recognized by CAD antibody (Millipore, ab16926) (Figure 3g). More importantly, because the concentrations at which the two enzymes cleaved DNA were of the same order of magnitude, demonstrating that $\mathrm{AChE}_{\mathrm{S}}$-DNase activity was comparable to that of CAD (Figure $3 \mathrm{~h}$ ). Similar to AChE-T547 and CAD, the other apoptotic DNases, CRN-4/RNase T [29], CYP-13/CYPE [30], and CPS-6/ EndoG [12], degraded DNA at micromolar concentrations. Although the activity of these enzymes is much lower than that of DNase I, this is normal and sufficient for effective DNase function during apoptosis.

When the peptide was incubated with other plasmids of various sizes, similar cleavage patterns were observed (Supplementary Figure S2A). In addition, hAChE-T547 degraded naked genomic DNA (Supplementary Figures S2B-E), which produced a smear pattern similar to that produced by the digestion of linearized plasmid (Supplementary Figure S2F).

\section{The purified mouse $A C h E_{S}$ polypeptide cleaves naked DNA}

To determine whether $\mathrm{AChE}_{\mathrm{S}}$ derived from other species possess DNA cleavage activity, mouse $\mathrm{AChE}_{\mathrm{S}}$ aa 32-579 (mAChE-T548), which was provided by Dr Palmer Taylor (Department of Pharmacology, University of California, San Diego, USA), and purified as described previously [31, 32] (Supplementary Figure S3A, lanes 2 and $2^{\prime}$ ). Similar to hAChE-T547, mAChE-T548 cleaved both plasmid and naked genomic DNA efficiently (Supplementary Figures S3B-E). 
a
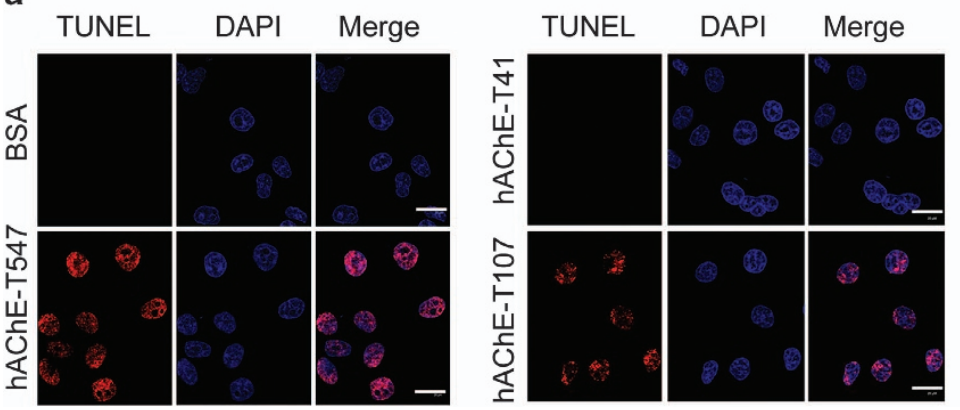

b

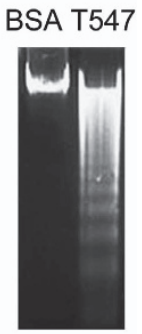

Figure 5 Synaptic acetylcholinesterase $\left(\mathrm{AChE}_{\mathrm{S}}\right)$ polypeptides digest chromosomal DNA in pre-fixed HeLa cells. HeLa cells were pre-fixed with $4 \%$ paraformaldehyde and permeabilized with $0.5 \%$ Triton X-100 before incubation with hAChE $\mathrm{S}_{\mathrm{S}}$ polypeptides. (a) Confocal images showing deoxynucleotidyl transferase (TdT)-mediated dUTP nick end labeling (TUNEL)-stained nuclei of HeLa cells. The pre-fixed and permeabilized HeLa cells were incubated with hAChE-T547 (0.2 $\mu \mathrm{m})$ (left panel) or with hAChE$\mathrm{T} 107(5 \mu \mathrm{M})$ (right panel) at $37^{\circ} \mathrm{C}$ for $6 \mathrm{~h}$. The TUNEL assay was then performed and the confocal images were taken. Bovine serum albumin (BSA) $(0.2 \mu \mathrm{m})$ and T41 $(5 \mu \mathrm{m})$ were used as negative controls, respectively. Scale bar, $20 \mu \mathrm{m}$. (b) Agarose gel images showing DNA fragmentation in pre-fixed HeLa cells incubated with hAChE-T547 $(21 \mu \mathrm{M})$ at $37^{\circ} \mathrm{C}$ overnight. BSA $(21 \mu \mathrm{M})$ was used as a negative control. DAPI, 4',6-diamidino-2-phenylindole.

These data indicated the DNase activity of mouse $\mathrm{AChE}_{\mathrm{S}}$.

The $N$ terminus of $A C h E_{S}$, but not its cholinesterase active center, is responsible for its DNA cleavage activity

We investigated whether the cholinesterase active center of $\mathrm{AChE}_{\mathrm{S}}$ also contributes to its DNase activity by using AChE inhibitors (AChEIs) $(10 \mu \mathrm{M}$ huperzine A, $1 \mu \mathrm{M}$ tacrine and $13 \mu \mathrm{M}$ donepezil). The acetylcholinesterase activity of mAChE-T548 was markedly inhibited by AChEIs (Supplementary Figure S4A), but its DNA cleavage activity was not (Supplementary Figure S4B). These data suggested that the functional domain responsible for the DNase activity of $\mathrm{AChE}_{\mathrm{S}}$ is distinct from that for its cholinesterase activity. To further confirm this suggestion, $\mathrm{AChE}_{\mathrm{S}}$ residues S234, E365 and $\mathrm{H} 478$ of the catalytic triad contributing to its cholinesterase activity were all mutated to alanine (A) to generate pEGFP-NLS$\mathrm{AChE}_{\mathrm{S}}$ (S234A, E365A, H478A). This construct expresses a mutant $\mathrm{AChE}_{\mathrm{S}}\left(\mathrm{mtAChE}_{\mathrm{S}}\right)$ fusion protein with a NLS at its $\mathrm{N}$ terminus and GFP at its $\mathrm{C}$ terminus (NLS-mtAChE $\mathrm{S}_{\mathrm{S}}$-GFP) (Supplementary Figure S4C). As expected, acetylcholine hydrolysis activity was completely abolished in the $\mathrm{mtAChE}_{\mathrm{S}}$, verifying that the catalytic triad is necessary for its hydrolyzing acetylcholine (Supplementary Figure S4D). If the cholinesterase active center also contributes to its DNA cleavage activity, the nucleus-localized $\mathrm{mtAChE}_{\mathrm{S}}$ would lose the capacity to initiate apoptosis. However, it still stimulated cell apoptosis to a similar degree to that induced by wild-type (wt)-AChE $\mathrm{A}_{\mathrm{S}}$ (Supplementary
Figures S4E-G). These results demonstrate that the catalytic triad of $\mathrm{AChE}_{\mathrm{S}}$ is indispensable for its cholinesterase activity, but is irrelevant to its DNase activity.

To verify that DNA cleavage in the cell-free hydrolysis system was caused by the $\mathrm{AChE}_{\mathrm{S}}$ polypeptide itself but not by other DNase contaminants, we mapped the functional domain responsible for the DNase activity of $\mathrm{AChE}_{\mathrm{S}}$ by screening the fragments with the ability to initiate apoptosis. Therefore,

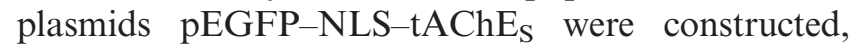
which respectively encode the truncated $\mathrm{AChE}_{\mathrm{S}}$ $\left(\mathrm{tAChE}\right.$ ) forms, including $\mathrm{AChE}_{\mathrm{S}}$ aa 2-247, aa 2-191, aa 2-138, and aa 2-72 (Figure 4a). The tAChE $\mathrm{C}_{\mathrm{S}}$ forms were fused with NLS at the N terminus and GFP at the C terminus. NLS-tAChE $\mathrm{S}_{\mathrm{S}}-247,-191$, and -138 showed the same strong apoptosis-inducing capacity as the NLS-(wt-AChE $E_{S}$, whereas NLS-tAChE $\mathrm{S}^{-72}$ did not (Figures $4 \mathrm{~b}$ and $\mathrm{c}$ ). These data confirmed that the pro-apoptotic fragment of $\mathrm{AChE}_{\mathrm{S}}$ is localized within aa $2-138$, and aa $72-138$ is indispensable.

Next, we investigated whether $\mathrm{AChE}_{\mathrm{S}}$ aa 2-138 possesses DNA cleavage activity. The 31 amino-acid residues at its $\mathrm{N}$ terminus form a signal peptide for the translocation of precursor AChE into the lumen of the endoplasmic reticulum [1,33]. Furthermore, neither hAChE-T547 nor mAChE-T548 contains the signal peptide, but both cleave DNA efficiently. Therefore, we hypothesized that $\mathrm{AChE}_{\mathrm{S}}$ aa 1-31 is irrelevant to the DNA cleavage activity. The polypeptides, human $\mathrm{AChE}_{\mathrm{S}}$ aa 32-138 (hAChE-T107) and aa 32-72 (hAChE-T41), were synthesized and purified by 
a

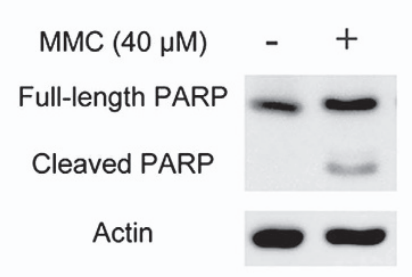

C

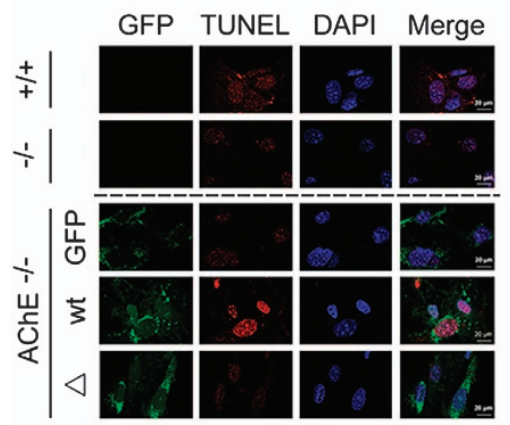

b

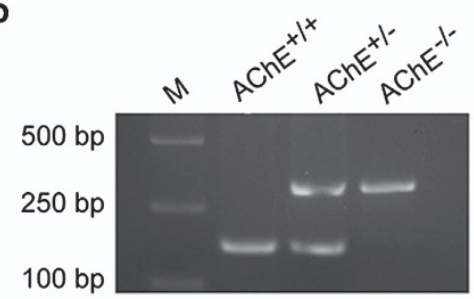

d

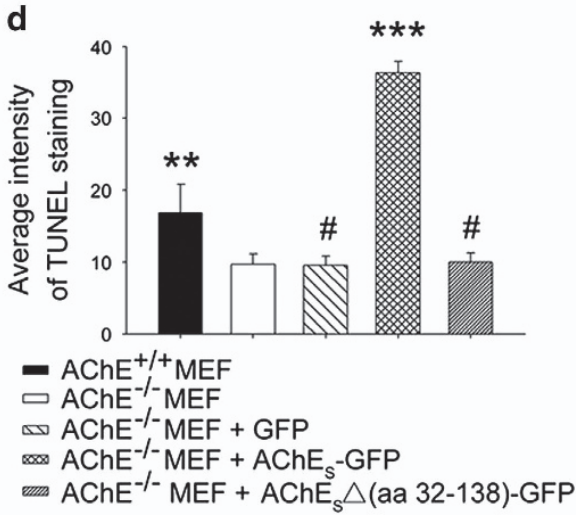

Figure 6 Endogenous synaptic acetylcholinesterase $\left(\mathrm{AChE}_{\mathrm{S}}\right)$ participates in DNA cleavage via aa 32-138 during apoptosis. (a) Immunoblot analysis of the apoptosis induced by mitomycin C (MMC) in mouse embryonic fibroblasts (MEFs). The cells were treated with $\mathrm{MMC}(40 \mu \mathrm{m})$ for $36 \mathrm{~h}$ prior to western blot analysis to detect cleaved poly(adenosine diphosphate ribose) polymerase (PARP) (a biomarker of apoptosis) using PARP antibody (Cell Signaling Technology, \#9545). (b) Identification of AChE knockout embryonic mice by reverse transcription-PCR. (c) Confocal images showing DNA cleavage in apoptotic $\mathrm{AChE}^{+/+}$or $\mathrm{AChE}^{-/-}$ MEFs. Cells were seeded $\left(5 \times 10^{4}\right)$ on coverslips in a 24 -well plate. Upper panels: $48 \mathrm{~h}$ later, the cells were treated with $40 \mu \mathrm{M} M M C$ (Sigma-Aldrich) for $36 \mathrm{~h}$ and the TUNEL assay was performed. Lower panels: at $4 \mathrm{~h}$ after seeding, the cells were infected with lentiviruses encoding the indicated proteins, where 'wt' indicates wt-AChE $E_{S}-$ GFP and ' $\Delta$ ' indicates AChE $\Delta$ (aa 32-138)-GFP. After a further $44 \mathrm{~h}$, the infected cells were exposed to $40 \mu \mathrm{M} M \mathrm{MC}$ for $36 \mathrm{~h}$. Then, the TUNEL assay was performed and analyzed by confocal microscopy. Scale bar, $20 \mu \mathrm{m}$. (d) Average intensity of TUNEL staining in MEFs was quantified by Leica Confocal Software. Fifty cells were randomly selected and analyzed in each experimental group in c. Values represent the mean \pm s.d. ${ }^{* *} P<0.01,{ }^{* * *} P<0.001,{ }^{\#} P>0.05$ vs $\mathrm{AChE}^{-/-}$MEFs without virus infection. Two-tailed Student's $t$-test. The data shown are representative of two independent experiments. DAPI, 4',6-diamidino-2-phenylindole; GFP, green fluorescence protein.

Ketai BioTech (Shanghai, China) (Supplementary Figures S5A and B). Purified synthetic peptides often contain a small amount of intermediate products composed of partially protected sequences carrying protecting groups and truncated sequences missing one or two N-terminal residues [34]. Analysis of peak fractions by high-performance liquid chromatography is a common method used to identify the purity of chemically synthesized peptides [34]. Highperformance liquid chromatography analysis resulted in one major peak revealing $93.9 \%$ purity of the product hAChE-T107 and 96.1\% purity of the hAChET41 (Supplementary Figure S5A and B). The peptides were dissolved in the hydrolysis buffer with or without $\mathrm{Mg}^{2+}$ and (or) $\mathrm{Ca}^{2+}$ and folded slowly at $4{ }^{\circ} \mathrm{C}$. hAChE-T107 digested both plasmid and naked genomic DNA (Figures 4d-f; Supplementary Figures S5C-D). Furthermore, the peptide degraded the linearized plasmid DNA into smears similar to those produced by the digestion of naked genomic DNA (Supplementary Figure S5E). DNA cleavage by the peptide at $\mathrm{pH} 7.5$ was slightly more efficient than that at any other $\mathrm{pH}$ (Figure $4 \mathrm{~g}$ ). Moreover, $\mathrm{Mg}^{2+}$ and $\mathrm{Ca}^{2+}$ showed a synergistic effect on the enzyme activity (Figure 4h). These data are consistent with those obtained by incubation of DNA with the purified hAChE-T547 (Figure 3). However, hAChET41 $(10 \mu \mathrm{M})$ showed no DNA cleavage activity (Figures $4 \mathrm{~d}$ and $\mathrm{e})$.

These data suggest that aa $32-138$ is the functional domain responsible for $\mathrm{AChE}_{\mathrm{S}}-\mathrm{DNase}$ activity, which is consistent with the observation that $\mathrm{AChE}_{\mathrm{S}}$ aa 2-138 possesses the pro-apoptotic capacity.

\section{Both the purified and the synthesized $A C h E_{S}$ peptides} degrade chromosomal DNA in pre-fixed cells

In addition to naked DNA, chromosomal DNA was digested by $\mathrm{AChE}_{\mathrm{S}}$, as evidenced by positive TUNEL 

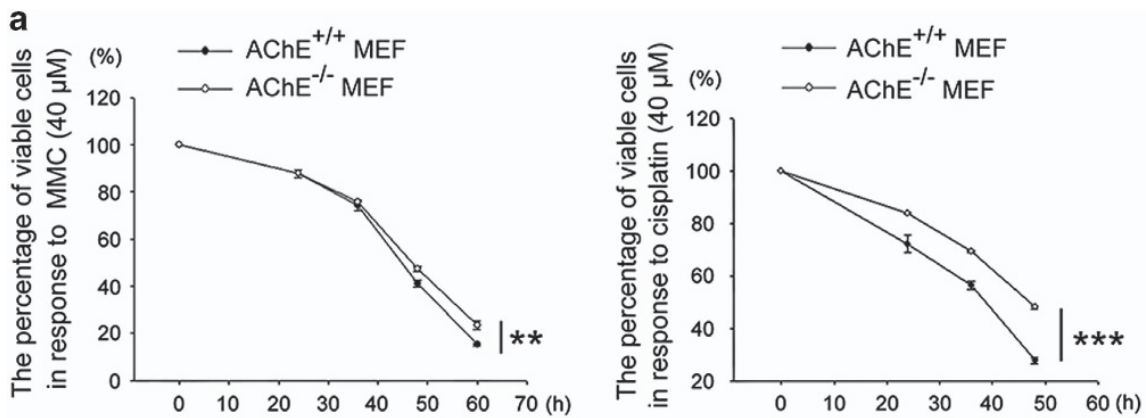

b

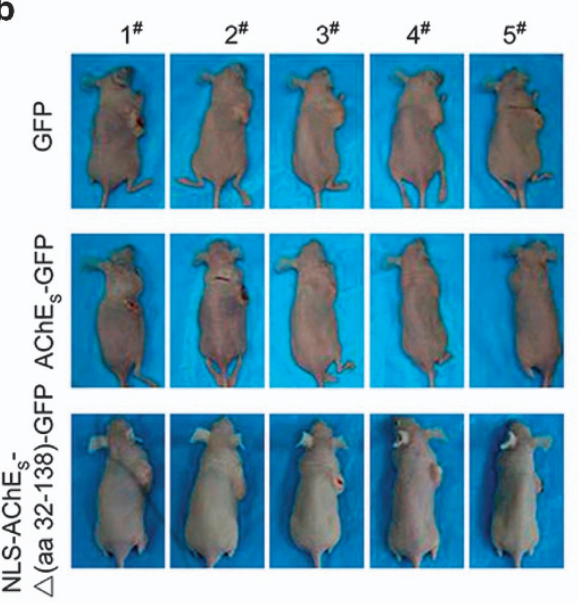

c
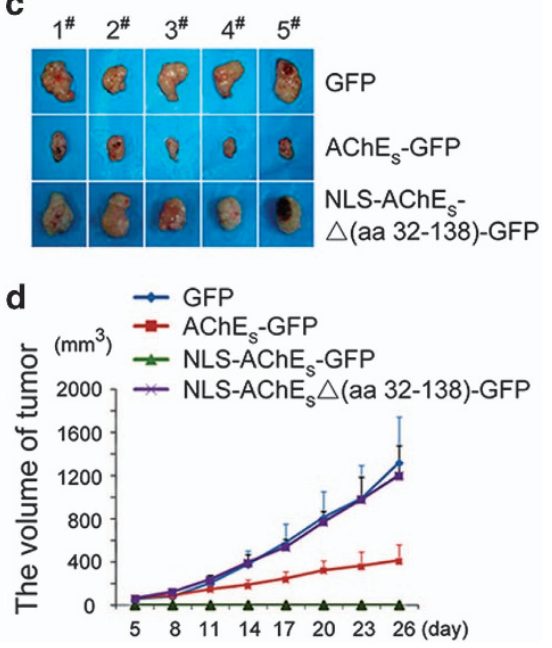

Figure 7 Endogenous synaptic acetylcholinesterase $\left(\mathrm{AChE}_{\mathrm{S}}\right)$ participates in apoptosis via aa 32-138. (a) Cell viability curves of mouse embryonic fibroblasts (MEFs). $\mathrm{AChE}^{+/+}$and $\mathrm{AChE}^{-/-} \mathrm{MEFs}$ were added to 96 -well plates $\left(2 \times 10^{4}\right.$ cells/well). After $24 \mathrm{~h}$, the cells were treated with or without mitomycin $\mathrm{C}(\mathrm{MMC})(40 \mu \mathrm{M})$ or cisplatin $(40 \mu \mathrm{m})$ (Sigma-Aldrich). The percentage of viable cells at the indicated time points was detected by the 3-(4,5-dimethylthiazol-2-yl)-2,5-diphenyltetrazoliumbromide assay. ${ }^{* *} P<0.01$, ${ }^{* * *} P<0.001$. The data are presented as the mean \pm s.d. of triplicate samples from one experiment that is a representative of three independent experiments. (b) BALB/c mice bearing tumors on day 26 after subcutaneous injection of HeLa cells. HeLa cells stably expressing the indicated proteins were counted and collected by fluorescence-activated cell sorting and then subcutaneously injected into Balb/c mice $\left(5 \times 10^{6}\right.$ cells/mouse). (c) Tumors isolated from the mouse in the correlating panel in b. (d) Tumor growth curve. From 5 days after cell injection, the size of tumors was measured every 3 days using vernier calipers. Tumor volume was calculated using the formula: $V=a b^{2} \pi / 6$, where ' $a$ ' represents the length and ' $b$ ' represents the width. GFP, green fluorescence protein; NLS, nuclear localization signal.

staining in the pre-fixed and permeabilized HeLa cells after incubation with hAChE-T547 $(0.2 \mu \mathrm{M})$ and hAChE-T107 $(5 \mu \mathrm{M})$ at $37^{\circ} \mathrm{C}$ for $6 \mathrm{~h}$. In contrast, bovine serum albumin $(0.2 \mu \mathrm{M})$ or hAChE-T41 $(5 \mu \mathrm{M})$ failed to do so (Figure 5a). Digestion of DNA by endogenous DNases in nuclei is dependent on the accessibility of DNA; however, endogenous DNases cannot access chromosomal DNA in normal living cells. For this reason, the endogenous DNases, including EndoG and CAD/DFF40, can no longer 'actively' perform biochemical reactions in pre-fixed cells, and thus, the resulting digestion must be the result of the direct action of the $\mathrm{AChE}_{\mathrm{S}}$ polypeptide that we have supplied. In this case, $\mathrm{AChE}_{\mathrm{S}}$ initiated the chromosomal DNA cleavage independent of the function of endogenous DNase, including CAD/ DFF40 and EndoG.

TUNEL assays are commonly used to detect DNA fragmentation and strand breakage by the generation of free 3'-hydroxyl-terminal ends [10, 35]. Therefore, positive TUNEL staining caused by hAChE-T547 and hAChE-T107 in pre-fixed cells demonstrates that $\mathrm{AChE}_{\mathrm{S}}$ degrades chromosomal DNA, generating 3'-hydroxyl DNA breaks. The DNA fragmentation capacity of $\mathrm{AChE}_{\mathrm{S}}$ was further confirmed by DNA ladder formation (Figure 5b). The purified hAChET547, rather than the synthesized hAChE-T107, was used in this assay because the DNA cleavage activity of 
hAChE-T107 was much weaker than that of hAChET547. This difference might be attributed to the nonoptimal folding of the synthesized peptide.

\section{Nuclear-localized $A C h E_{S}$ degrades DNA independently of CAD/DFF40 and EndoG}

To detect the functional relationships between NLS$\mathrm{AChE}_{\mathrm{S}}$ and the other apoptotic DNases, and more importantly, with caspase-activated CAD/DFF40 and EndoG, we pre-inhibited caspase activation using the pan-caspase inhibitor Z-VAD-FMK $(150 \mu \mathrm{M})$ $1 \mathrm{~h}$ prior to overexpressing NLS-AChE in HeLa cells. As expected, caspase activation was blocked (Supplementary Figure S6A). In the absence of activated caspase-3, CAD/DFF40 is bound by its chaperone ICAD/DFF45 and fails to have a role in apoptotic DNA cleavage [13, 26]. Besides, EndoG, another caspase-dependent apoptotic DNase, was retained outside the nucleus by the inhibitor and was unable to gain access to the nuclear DNA (Supplementary Figure S6B). However, DNA cleavage was still stimulated by

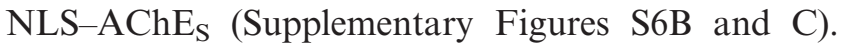
These data imply that nuclear-translocated $\mathrm{AChE}_{\mathrm{S}}$ functions as an apoptotic DNase in a CAD- and EndoG-independent manner. This is consistent with the observation that $\mathrm{AChE}_{\mathrm{S}}$ polypeptides cleave chromosomal DNA in pre-fixed cells where CAD/DFF40 [36] and EndoG are sequestered in the cytoplasm (Figure 5a).

\section{$A C h E_{S}$ degrades apoptotic DNA via its functional domain a $32-138$}

The capacity of $\mathrm{AChE}_{\mathrm{S}}$ to cleave DNA during apoptosis was further confirmed by the function of endogenous $\mathrm{AChE}_{\mathrm{S}}$. During apoptosis induced by mitomycin $\mathrm{C}(\mathrm{MMC})(40 \mu \mathrm{M})$ in mouse embryonic fibroblasts (MEFs) (Figure 6a), DNA cleavage in MEFs with or without the wt $A C h E$ gene $\left(A C h E^{+/+}\right.$ MEFs, $A C h E^{-1-}$ MEFs) (Figure 6b) was detected by TUNEL staining. In comparison with $\mathrm{AChE}^{+/+} \mathrm{MEFs}$, $A C h E$ gene knockout significantly impaired DNA cleavage (Figure 6c, upper panel). Furthermore, overexpression of the wt- $\mathrm{AChE}_{\mathrm{S}}$ rescued the impaired DNA cleavage, whereas (aa 32-138)-deleted $\mathrm{AChE}_{\mathrm{S}}$ $\left(\mathrm{AChE}_{\mathrm{S}} \Delta\right.$ (aa 32-138)) did not (Figure 6c, lower panel, and Figure 6d; Supplementary Figure S7). Together with the data showing DNA cleavage activity of $\mathrm{AChE}_{\mathrm{S}}$ aa 32-138 in vitro, these results confirm that $\mathrm{AChE}_{\mathrm{S}}$ performs an apoptotic DNase function via its aa 32-138 domain, although the mechanism underlying this activity requires further investigation.
$A C h E_{S}$ prompts apoptosis via its DNA cleavage domain Consistent with the impaired DNA cleavage in apoptotic $A C h E^{-1-}$ MEFs, $A C h E$ gene knockout also significantly attenuated drug-induced apoptosis (Figure 7a), thus confirming the pro-apoptotic role of endogenous AChEs. To determine whether $\mathrm{AChE}_{\mathrm{S}}$ prompts apoptosis via its DNA cleavage domain, we attempted to establish stable cell lines. In accordance with the apoptosis-inducing effects of nuclear-localized $\mathrm{AChE}_{\mathrm{S}}$ (Figures 1c-f), we were unable to establish the NLS-AChE $E_{S}-$ GFP-overexpressing stable cell line because the cells could not survive, and certainly, the transfected cells lose tumorigenicity in BALB/c nude mice. In contrast, the stable cell line expressing NLS$\mathrm{AChE}_{\mathrm{S}} \Delta$ (aa 32-138)-GFP was established successfully (Supplementary Figure S8) and showed a similar rate of tumor development compared with those stably expressing GFP (Figures 7b-d). These data reveal that the DNA cleavage domain aa $32-138$ is also the proapoptotic domain of $\mathrm{AChE}_{\mathrm{S}}$, through which $\mathrm{AChE}_{\mathrm{S}}$ participates in apoptosis. The obviously lowered rate of tumor formation by $\mathrm{AChE}_{\mathrm{S}}-\mathrm{GFP}$-overexpressing cells (Figure 7d) can be attributed to the fact that overexpression of $\mathrm{AChE}_{\mathrm{S}}$ slows down cell growth [37].

\section{Discussion}

$\mathrm{AChE}_{\mathrm{S}}$ has emerged as an important contributor to apoptosis in various types of cells [2-6]. However, it is inexplicable that cholinergic neurons with high basal levels of $\mathrm{AChE}_{\mathrm{S}}$ protein show long-term growth and normal morphology [3]. In the light of the finding that $\mathrm{AChE}_{\mathrm{S}}$ is a bifunctional enzyme with acetylcholine hydrolysis and DNA cleavage domains, a nuclear translocation-dependent role for $\mathrm{AChE}_{\mathrm{S}}$ may shed light on this question. Despite abundant $\mathrm{AChE}_{\mathrm{S}}$ expression in cholinergic neurons, under normal conditions the protein is localized outside of the nucleus and is inaccessible to the chromosomal DNA. Consequently, $\mathrm{AChE}_{\mathrm{S}}$ is unable to act as a DNase, which makes it understandable that the neurons with high basal AChE levels survive normally. In this case, $\mathrm{AChE}_{\mathrm{S}}$ might perform its canonical function to terminate neurotransmission by hydrolysis of $\mathrm{ACh}$. However, in response to $\mathrm{A} \beta$ stress, $\mathrm{ACh} \mathrm{E}_{\mathrm{S}}$ translocates into the nucleus and DNA cleavage occurs (Supplementary Figure S9). This translocation event might act as a critical switch of the canonical function of $\mathrm{AChE}_{\mathrm{S}}$ as a cholinesterase to a noncanonical function as a DNase.

The optimum $\mathrm{pH}$ for enzyme activity depends on the environment in which the enzyme normally works. 
In the stepwise degradation of DNA in apoptotic mammalian cells, DFF40 and EndoG act at the early stages to initiate DNA breakage [27]. Consistent with this, these enzymes show maximum DNA cleavage activity at $\mathrm{pH} 7.5$, near to the physiological $\mathrm{pH} 7.4$ [23]. In contrast, DNase II, required for metabolizing residual DNA in dying cells, acts at a later stage when acidification occurs $[10,38]$ and its optimal $\mathrm{pH}$ is 5.0-6.0 [38, 39]. We proposed that the optimum $\mathrm{pH}$ for an apoptotic DNase is closely correlated with the stage of apoptosis at which it functions. The optimal $\mathrm{pH} 7.5$ for $\mathrm{AChE}_{\mathrm{S}}$ suggests that the enzyme acts in early stage apoptosis. This hypothesis was supported by the observation of (NLS-AChE $)_{S}$-induced CAD/DFF40and EndoG-independent 3'hydroxyl DNA cleavage after overexpression in normal living cells without treatment with any other stimuli.

The requirement for divalent cations for DNA cleavage is a general feature of apoptotic DNases. Both DFF40 [23] and EndoG [21] are $\mathrm{Mg}^{2+}$-endonucleases, requiring $\mathrm{Mg}^{2+}$ and are not costimulated by $\mathrm{Ca}^{2+}$. However, DNase I [13] requires both $\mathrm{Ca}^{2+}$ and $\mathrm{Mg}^{2+}$ for DNA hydrolysis. One $\mathrm{Ca}^{2+}$ stabilizes the functional DNase I structure. The presence of $\mathrm{Mg}^{2+}$ in close proximity to the catalytic pocket of DNase I reinforces the idea of a cation-assisted hydrolytic mechanism [13]. Our study demonstrates that $\mathrm{AChE}_{\mathrm{S}}$ shows characteristic $\mathrm{Ca}^{2+}-\mathrm{Mg}^{2+}$-dependent DNase activity, similar to that of DNase I. DNA cleavage in the (hAChE-T547)containing reaction system was not caused by DNase I contamination, because G-actin effectively inhibited the DNA cleavage by DNase I but did not inhibit that by hAChE-T547. Overexpression of the nuclearlocalized wt rather than aa 32-138-deleted $\mathrm{AChE}_{\mathrm{S}}$ rescued the attenuated DNA cleavage in apoptotic $A C h E^{-1-}$ MEFs. Together with the demonstration of the DNase activity of the synthesized $\mathrm{AChE}_{\mathrm{S}}$ aa $32-138$, these results further confirm that $\mathrm{AChE}_{\mathrm{S}}$ performs its DNase function via its aa 32-138 domain.

The mechanism by which AChE acts as a common and crucial component in the induction of apoptosis has rarely been investigated. It has been reported that the cytoplasm is the subcellular compartment in which AChE mediates apoptosis, where it participates in apoptosome formation by interaction with caveolin-1, and subsequently with cytochrome $c$ and proteaseactivating factor-1 (Apaf-1) [40]. Another report documents that $\mathrm{N}$-terminally extended $\mathrm{AChE}_{\mathrm{S}}$ induces apoptosis via the structure of its cholinesterase active center, whereas the cholinesterase activity itself is irrelevant to the induction of apoptosis [41].
N-terminally extended $\mathrm{AChE}_{\mathrm{S}}$ is located in the membrane with the catalytic domain positioned toward the extracellular space, where it might act as a ligand-activated receptor to mediate intracellular signaling in response to extracellular cues [41]. In this study, $\mathrm{AChE}_{\mathrm{S}}$ was found to promote apoptosis by its DNase function. The functional domain was found residing within $\mathrm{AChE}_{\mathrm{S}}$ aa 32-138, losing cholinesterase activity, thus indicating no direct necessity for cholinesterase function in pro-cytotoxic DNase action.

The lack of involvement of cholinesterase function in pro-cytotoxic DNase activity sheds light on the following question. Some AChEIs, such as huperzine A, tacrine, and donepezil, have the ability to partially inhibit cell apoptosis caused by some insults [4-6, 42-44], whereas they do not affect DNA cleavage by $\mathrm{AChE}_{\mathrm{S}}$. AChEIs protect cells against apoptosis via different mechanisms, depending on the nature of the toxic insult [45]. Studies also indicate that AChEIs impair the apoptosis of neurons by modulating gene expression, including downregulation of pro-apoptotic p53, c-jun, and bax, and upregulation of anti-apoptotic Bcl-2 [46, 47]. Alternatively, it has been suggested that the neuroprotective effect of donepezil is mediated via direct binding to an allosteric site on the nicotinic acetylcholine receptor (nAChR) [45, 48]. This apoptosis-inhibitory effect is independent of the blockage of AChE [45, 48]. Moreover, some AChEIs fail to protect cells from apoptosis induced by certain insults [45]. Thus it is clear that AChEIs inhibit apoptosis in a cholinesterase activity-dependent or -independent manner. Taken together, this explains why some AChEIs exert anticytotoxic effects without inhibition of its DNase activity.

The findings of this study may help to elucidate the mechanisms underlying neuron loss during Alzheimer's disease (AD) progression. It has been found that $\mathrm{AChE}_{\mathrm{S}}$ is expressed abundantly in normal hippocampus, whereas $\mathrm{AChE}_{\mathrm{R}}$ is rarely expressed [49]. The hippocampus is one of the most vulnerable regions to apoptotic stimuli during development of AD [50]. The results of this study indicate that high-level $\mathrm{AChE}_{\mathrm{S}}$ expression confers apoptotic susceptibility on neurons, which is strongly supported by other studies. $\mathrm{AChE}_{\mathrm{S}}$ transgenic mice exhibited increased neural apoptosis in hippocampi and the mice show impaired acquisition and retention of knowledge, whereas $\mathrm{AChE}_{\mathrm{R}}$ transgenic mice did not [51]. In this study, $A \beta$ (a type of toxin found in the AD brain) was found to be deposited in a brain section prepared from a 1-year-old B6C3-Tg (APPswe,PSEN1dE9)85Dbo/J transgenic mouse (a 
mouse model of AD), and AChE was found to be translocated into the nuclei (Supplementary Figures $\mathrm{S} 9 \mathrm{~A}$ and $\mathrm{B})$. In addition, in response to $\mathrm{A} \beta$-induced neurotoxicity, primary hippocampal neurons showed nuclear translocation of $\mathrm{AChE}_{\mathrm{S}}$ and chromosomal DNA cleavage (Supplementary Figure S9C). Together with the observation that $\mathrm{AChE}_{\mathrm{S}}$ exerts a DNAhydrolysis function after translocation into the nucleus, these data suggest that nuclear translocation and subsequent cleavage of chromosomal DNA is one of the functions of $\mathrm{AChE}_{\mathrm{S}}$ in neuron loss during $\mathrm{AD}$ progression, although this speculation requires further investigation.

In summary, this study demonstrates that $\mathrm{AChE}_{\mathrm{S}}$ performs a vital function as a DNase in apoptosis. The stepwise events, including upregulated expression, nuclear translocation, subsequent binding with and digestion of chromosomal DNA, constitute the mechanism by which $\mathrm{AChE}_{\mathrm{S}}$ mediates cell apoptosis. The region comprising aa $32-138$ is the indispensable domain conferring apoptotic DNase activity on $\mathrm{AChE}_{\mathrm{S}}$. However, the mechanism by which AChEs is activated during apoptosis and how $\mathrm{AChE}_{\mathrm{S}}$ and other DNases are coordinated and recruited into apoptotic machinery remain to be determined. Nevertheless, this work elucidates a novel role of $\mathrm{AChE}_{\mathrm{S}}$, and indicates the potential for the development of novel drugs targeting the DNase activity of $\mathrm{AChE}_{\mathrm{S}}$ for the treatment of neurodegenerative diseases, such as AD.

\section{Materials and Methods}

\footnotetext{
Animals

Heterozygous AChE gene knockout $\left(\mathrm{AChE}^{+/-}\right)$mice (stock number: 005987; strain name: 129-Achetm1Loc/J) were purchased from the Jackson Laboratory, Bar Harbor, ME, USA. They were bred, and AChE-deficient embryo mice were identified as described previously [3, 44]. B6C3-Tg (APPswe, PSEN1dE9) 85Dbo/Mmjax transgenic mice (stock number: 004462) were also purchased from the Jackson Laboratory. The following primers were used for identification of the transgenic mice: PS1dE9 forward primer 5'-CCTCTTTGTGACTAT GTGGACTGATGTCGG-3', reverse 5'-GTGGATAACCCC TCCCCCAGCCTAGACC-3'; APPswe: forward primer 5'GACTGACCACTCGACCAGGTTCTG-3', reverse 5'-CTTG TAAGTTGGATTCTCATATCCG-3'. Four-week-old female $\mathrm{BALB} / \mathrm{c}$ mice and male Sprague-Dawley rats $(250-300 \mathrm{~g})$ were purchased from Shanghai SLAC Laboratory Animal Co. Ltd (Shanghai, China). All animals were housed under standard conditions of $12 \mathrm{~h}$ light $/ 12 \mathrm{~h}$ dark cycles with free access to food and water. The experimental protocols were approved by the Institutional Animal Ethics Committee of the Shanghai Institutes for Biological Sciences.
}

Cell culture, transfection, apoptosis induction, and generation of stable cell lines

HeLa and 293 T cells were obtained from the Shanghai Cell Resource Center, Chinese Academy of Science. HEK-293 S cells lacking $N$-acetlygluocosaminyltransferase I activity $\left(\mathrm{GnTI}^{-/-}\right.$ HEK 293S) were provided by Dr Palmer Taylor (Department of Pharmacology, University of California). All cells were cultured in Dulbecco's modified Eagle's medium (Invitrogen, Carlsbad, CA, USA) supplemented with 10\% fetal calf serum (Tianhang Biological Technology Co. Zhejiang, China). Primary MEFs were isolated from $A C h E^{-1-}$ or $A C h E^{+/+}$E13 129 mouse embryos as described previously [52] and cultured in Dulbecco's modified Eagle's medium supplemented with 10\% fetal calf serum. Primary hippocampal neurons were isolated from the Sprague-Dawley rats as described previously [53] and cultured in Neurobasal-A medium supplemented with GIBCO B-27 (Invitrogen). All cells were cultured at $37^{\circ} \mathrm{C}$ in a humidified atmosphere of $95 \%$ air and $5 \% \mathrm{CO}_{2}$. FuGENEHD Transfection Reagent (Roche Diagnostics, Mannheim, Germany) was used for transfection of plasmids into HeLa cells, according to the manufacturer's instructions. For infection of MEFs with the lentiviral system (System Biosciences, Mountain View, CA, USA), medium from 293T cells co-transfected with pCMV-delta-8.2, pCMV-VSV-G, and pCDH-CMV-MCSEF1-Puro-GFP/AChE ${ }_{S}-G_{F P} / A_{C h E} \quad \Delta$ (aa 32-138)-GFP using lipofectamine 2000 (Invitrogen) was collected, centrifuged at $2500 \mathrm{~g}$ for $10 \mathrm{~min}$ and filtered $(0.45 \mu \mathrm{m}$ pore size $)$ at $48 \mathrm{~h}$ post transfection. The supernatant was applied to MEF cells for $48 \mathrm{~h}$ followed by treatment with $4 \mu \mathrm{M}$ MMC (Sigma-Aldrich, St Louis, MO, USA) for $36 \mathrm{~h}$. Cell apoptosis was detected by the TUNEL assay. For generation of HeLa cell lines stably expressing GFP or $\mathrm{AChE}_{\mathrm{S}}-\mathrm{GFP}$ or $\mathrm{NLS}-\mathrm{AChE}_{\mathrm{S}} \Delta$ (aa 32-138)-GFP, transiently transfected cells were grown in $1 \mathrm{mg} / \mathrm{ml} \mathrm{G} 418$ (Sigma-Aldrich) for 7 days after transfection. Pooled populations of G418-resistant cells were obtained and then continuously cultured in $200 \mu \mathrm{g} / \mathrm{ml}$ G418-containing culture medium. After 4 weeks, GFP-positive cells were further sorted using a FACSort flow cytometer (Becton Dickinson, CA, USA), cultured in $200 \mu \mathrm{g} / \mathrm{ml}$ G418-containing culture medium, and used for propagation.

\section{Preparation of polypeptide hAChE-T547}

GnTI-293 cells stably expressing human AChE aa 32-578 (hAChE-T547) were cultured in Dulbecco's modified Eagle's medium culture medium with $10 \%$ fetal calf serum and $2 \mu \mathrm{g} / \mathrm{ml}$ puromycin. Two days before protein purification, the culture medium was replaced by serum-free medium (UltraCULTURE; Biowhittaker, Walkersville, MD, USA) with 1\% L-glutamine. Human AChE-T547 was purified according to modified protocols, as described previously [54, 55].

\section{The dynamics of DNA-protein interactions}

The real-time kinetics of the interactions between hAChET547 and pEGFP-c1 plasmid DNA were examined using a BIACORE T100 system (GE Healthcare Biacore; Piscataway, NJ, USA). The protonated hAChE-T547 polypeptide, bovine serum albumin (irrelative control protein), and DNase I (positive control protein) (Sigma-Aldrich) were immobilized onto the 
activated sensor chips (Series S Sensor Chip CM5) (GE Healthcare Biacore). The pEGFP-c1 plasmids were diluted to $1.88 \times 10^{-6} \mathrm{M}$ in a running buffer $(10 \mathrm{~mm}$ HEPES, $\mathrm{pH} 7.5$, $2.5 \mathrm{mM} \mathrm{CaCl}_{2}, 5 \mathrm{~mm} \mathrm{MgCl}$ ) ((Sigma-Aldrich) and injected over the sensor chip surface at $20 \mu \mathrm{l} / \mathrm{min}$ at $37^{\circ} \mathrm{C}$ to generate $\sim 130$ response units on the surface of hAChE-T547 peptides. The plasmids were then further diluted in running buffer to the concentrations indicated in Figure $2 \mathrm{c}$, and injected at $37^{\circ} \mathrm{C}$ at a flow rate of $20 \mu \mathrm{l} / \mathrm{min}$ for $150 \mathrm{~s}$. Surface regeneration was achieved using a 2-min injection of the running buffer at 100, 30, and $20 \mu \mathrm{l} / \mathrm{min}$. Plasmid concentrations were analyzed in duplicate, and any background signal generated by the running buffer was subtracted. The data were analyzed using the Biacore T100 evaluation software (GE Healthcare Biacore).

\section{Plasmid cleavage assays}

AChE polypeptides were incubated with plasmid DNA in a cell-free hydrolysis system (5 mM Tris- $\mathrm{HCl}$ pH 7.5, $2.5 \mathrm{~mm} \mathrm{CaCl}_{2}$, $5 \mathrm{~mm} \mathrm{MgCl}_{2}$ ) for $6-12 \mathrm{~h}$ at $37^{\circ} \mathrm{C}$. The hydrolysis products were subjected to $1 \%$ agarose (Invitrogen) gel electrophoresis. The gel was stained with ethidium bromide and visualized using a Tanon 2500 gel imaging system (Bio-tanon, Shanghai, China).

TdT-mediated dUTP nick end labeling (TUNEL) assays

The TMR red in situ cell death detection kit was purchased from Roche, Basel, Switzerland. TUNEL assays were performed according to the manufacturer's instructions. The transfected HeLa cells grown on coverslips in 24-well plates were fixed with $4 \%$ paraformaldehyde for $15 \mathrm{~min}$ and permeabilized with $0.5 \%$ Triton X-100 for $10 \mathrm{~min}$ at room temperature (RT), followed by incubation with $18 \mu \mathrm{l}$ labeling solution plus $2 \mu \mathrm{l}$ enzyme solution at $37^{\circ} \mathrm{C}$ for $1 \mathrm{~h}$. Cell nuclei were stained with $0.1 \mu \mathrm{g} / \mathrm{ml} \mathrm{4',6-diami-}$ dino-2-phenylindole (Sigma-Aldrich) at RT for $5 \mathrm{~min}$. The labeled cells were then washed, transferred onto glass slides, and observed by laser scanning confocal microscopy.

\section{Assessment of acetylcholinesterase activity}

Acetylcholinesterase activity was examined using a modified Ellman method as described previously [44]. Collected cells were resuspended in potassium phosphate buffer ( $\mathrm{pH}$ 7.4) containing $0.5 \%$ Tween 20 and $1 \mathrm{M} \mathrm{NaCl}$, sonicated at $4{ }^{\circ} \mathrm{C}$ using an ultrasound generator, and centrifuged at $10000 \mathrm{~g}$ at $4{ }^{\circ} \mathrm{C}$ for $10 \mathrm{~min}$ to get rid of cells/debris. The supernatant was incubated with $25 \mu \mathrm{M}$ iso-OMPA in sodium phosphate ( $\mathrm{pH} 8.0$ ) containing $0.315 \mathrm{~mm} 5,5^{\prime}$-dithio-bis(2-nitrobenzoic acid) (DTNB) at $37^{\circ} \mathrm{C}$ for $30 \mathrm{~min}$. After addition of acetylthiocholine iodide (final concentration, $5 \mathrm{~mm}$ ), optical density values at $405 \mathrm{~nm}$ were measured spectrophotometrically every $5 \mathrm{~min}$ in a 96-well microtiter plate at $37^{\circ} \mathrm{C}$.

\section{Preparation of a double-stranded DNA oligonucleotide of NLS}

The single-stranded NLS oligonucleotides were synthesized by Sangon Biotech, Shanghai, China. Forward: 5'-gatct ATGCCAAAGAAGAAGCGTAAGGTTCCAAAGAAGAA GCGTAAGGTTa-3; reverse: 5'-agcttAACCTTACGCTTCT TCTTTGGAACCTTACGCTTCTTCTTTGGCATa-3'.
The single-stranded NLS oligonucleotides were dissolved in sterile distilled water to a concentration of $50 \mu \mathrm{M}$. The complementary single strands were added to the annealing buffer (10 mu Tris, pH 7.5-8.0, $50 \mathrm{~mm} \mathrm{NaCl}, 1$ mm EDTA) in a $1.5-\mathrm{ml}$ tube to a final concentration of $22.5 \mu \mathrm{M}$ and incubated in boiling water for $5 \mathrm{~min}$. The oligonucleotides were allowed to cool slowly to RT.

\section{Plasmid constructs}

pEGFP-AChE $\mathrm{S}_{\mathrm{S}}$ was generated as previously described [3]. For construction of $\mathrm{pEGFP}-\mathrm{NLS}-\mathrm{AChE}_{\mathrm{S}}$, the double-stranded NLS DNA with sticky ends (BglII-NLS-HindIII) was inserted between the BglII and HindIII sites in pEGFP-AChE For construction of pEGFP-NLS-AChE (S234A, E365A, H478A), site-directed mutagenesis was performed with the primary template plasmid $\mathrm{pEGFP}-\mathrm{NLS}-\mathrm{AChE}$. The following three pairs of primers were used in sequence: forward, 5'-CTGTTTGGGGAGGCCGCGGGAGCCGC-3' and reverse, 5'-GCGGCTCCCGCGGCCTCCCCAAACAG-3' for introducing a S234A change; forward, 5'-GTGTGGTGAAG GATGCGGGCTCGTATTTTCT-3' and reverse, 5'-AGAAA ATACGAGCCCGCATCCTTCACCACAC-3' for generation of a E365A change. Finally, forward, 5'-GATGGGGGTG CCCGCCGGCTACGAGATC-3' and reverse, 5'-GATCTCG TAGCCGGCGGGCACCCCCATC-3' for introducing a H478A change. For construction of pEGFP-NLS-tAChE encoding tAChE $\mathrm{S}_{\mathrm{S}}$, the tAChE $\mathrm{S}_{\mathrm{S}}$ complementary DNAs (cDNAs) encoding the aa $2-247$, aa 2-191, aa 2-138, and aa 2-72 fragments were amplified by PCR using the common forward primer 5'-cccaagcttAGGCCCCCGCAGTGTCT-3' and the reverse primers, 5'-ggaattcgCGGGGACAGCAGGTGCAT-3', 5'-gga attcgGGCCAGGAAGCCAAAGGC-3'， 5'-ggaattcgCCGGG GGTATGGTGTCC-3' and 5'-ggaattcgGGGTGGCTCCGC AAAGG-3, respectively. $\mathrm{tAChE}_{\mathrm{S}}$ flanked by restriction enzyme sites for 'HindIII' and 'EcoRI' were inserted between HindIII and EcoRI sites in pEGFP-NLS-AChE (replacement of $\mathrm{AChE}_{\mathrm{S}}$ by $\mathrm{tAChE} \mathrm{S}_{\mathrm{S}}$ ). For construction of $\mathrm{pEGFP}-\mathrm{NLS}-\mathrm{AChE}$ $\Delta$ (aa 32-138), aa 32-138 of $\mathrm{AChE}_{\mathrm{S}}$ in $\mathrm{pEGFP}-\mathrm{NLS}-\mathrm{AChE}_{\mathrm{S}}$ was replaced with a $X h o I$ restriction site using PCR technology with the forward primer 5'-ccgctcgagCCTACATCCCCCA CCCCTG-3' and the reverse primer $5^{\prime}$-ccgctcgagAGCCCCC ACTCCTCCACC-3'. For construction of pCDH-CMV-MCSEF1-Puro-AChE ${ }_{S} \Delta$ (aa 32-138)-EGFP and pCDH-CMVMCS-EF1-Puro-AChE S-EGFP, XbaI-AChE $_{\mathrm{S}} \Delta$ (aa 32-138)EGFP-BstBI cDNA and $X b a I-A C h E_{\mathrm{S}}-\mathrm{EGFP}_{-B s t \mathrm{BI}} \mathrm{cDNA}$ were amplified from $\mathrm{pEGFP}-\mathrm{NLS}-\mathrm{AChE}_{\mathrm{S}} \Delta$ (aa 32-138) and pEGFP-NLS-AChE $E_{S}$, respectively, using the forward primer 5'-gctctagaGCCACCATGAGGCCCCCGCAGTGTC-3' and the reverse primer 5'-gggttcgaaTTACTTGTACAGCTCGTC CATGCC-3'. For construction of pCDH-CMV-MCS-EF1Puro-EGFP, XbaI-EGFP-BstBI cDNA was amplified from the template pEGFP-n1 vector using the forward primer $5^{\prime}$-gcT CTAGAGCCACCATGGTGAGCAAGGGCGAGG-3' ${ }^{\prime}$ and the reverse 5'-gggTTCGAATTACTTGTACAGCTCGTCC ATGCC-3'. The three amplified fragments were all digested with $X b a \mathrm{I}$ and Bst BI (MBI Fermentas) and were then inserted between $X b a \mathrm{I}$ and BstBI sites in the pCDH-CMV-MCS-EF1Puro vector (System Biosciences). All the plasmids constructed were confirmed by direct sequencing before expression in cells. 
Time-lapse fluorescence microscopy imaging

HeLa cells grown in $\varphi 3.5 \mathrm{~cm}$-dishes were co-transfected with $\mathrm{AChE}_{\mathrm{S}}-\mathrm{GFP}$ and histone $\mathrm{H} 2 \mathrm{~b}-\mathrm{RFP}$ or with tubulin-GFP and histone H2b-RFP. After $24 \mathrm{~h}$, cells were exposed to $100 \mu \mathrm{m}$ $\mathrm{H}_{2} \mathrm{O}_{2}$. The changes in cell morphology and the distribution of $\mathrm{AChE}_{\mathrm{S}}-\mathrm{GFP}$ were then monitored under a Leica AS MDW live cell image acquisition system (Leica Microsystems, Wetzlar, Germany). Representative cells were photographed at $2 \mathrm{~min}$ intervals for $290 \mathrm{~min}$.

\section{Cell sorting by flow cytometry}

At $18 \mathrm{~h}$ after transfection, cells were harvested, centrifuged at $800 \mathrm{~g}$ for $10 \mathrm{~min}$, resuspended in cell culture medium $\left(1 \times 10^{7}\right.$ cells $/$ $\mathrm{ml}$ ), and filtered through a $40-\mu \mathrm{m}$ nylon mesh (BD Falcon, Bedford, ME, USA). GFP-positive cells were then sorted with a Becton Dickinson FACSort flow cytometer (excitation at $488 \mathrm{~nm}$ ).

\section{MTT assay of cell viability}

Cell viability is commonly measured using MTT assays [44]. MTT (Sigma-Aldrich, Shanghai, China) was dissolved in phosphate-buffered saline $(1 \times, \mathrm{pH} 7.2-7.4)$ to give a final concentration of $5 \mathrm{mg} / \mathrm{ml}$. MTT solution $(20 \mu \mathrm{l})$ was added to each well of a 96-well plate containing $100 \mu \mathrm{l}$ culture medium and then incubated at $37^{\circ} \mathrm{C}$ for $4 \mathrm{~h}$. The formazan crystals were dissolved in $100 \mu$ dimethyl sulfoxide. Finally, optical density values at $570 \mathrm{~nm}$ were measured by using a Multiscan MC3 microplate reader (Thermo Labsystems, Vantaa, Finland).

\section{Western blot analysis}

Western blot analysis was performed as described previously [3]. The following primary antibodies were used: mouse anti-GFP-tag (7G9) mAb (Abmart, Shanghai, China, 1:10 000), rabbit polyclonal anti-AChE antibody (1:1000) (Dr Palmer Taylor's laboratory). The secondary antibodies were goat anti-mouse-HRP (Santa Cruz, sc-2030, 1:5 000) and goat anti-rabbit-HRP (Santa Cruz, sc-2030, 1:5 000), respectively.

\section{AChE cytochemical staining}

Frozen sections of wt $\mathrm{B} 6 \mathrm{C} 3$ and $\mathrm{B} 6 \mathrm{C} 3 / \mathrm{Tg}$ (APPswe, PSEN1dE9)85Dbo/J mouse brains were prepared using standard procedures. AChE cytochemical staining was performed as described previously [3]. The specimens were incubated in $15 \mathrm{ml}$ of $0.1 \mathrm{M}$ sodium phosphate $(\mathrm{pH} 6.0)$ containing $10 \mathrm{mg}$ of acetylthiocholine iodide, $1 \mathrm{ml}$ of $0.1 \mathrm{~m}$ sodium citrate solution, $2 \mathrm{ml}$ of $30 \mathrm{~mm}$ copper sulfate solution, and $2 \mathrm{ml}$ of $5 \mathrm{~mm}$ potassium ferricyanide solution at RT for 4-8 h. Thereafter, the slides were incubated in Harris' hematoxylin solution for another $30 \mathrm{~s}$. The samples were then dehydrated with ethanol and sealed in neutral balsam. AChE staining was observed under a phase-contrast microscope.

\section{DNA ladder assay}

HeLa cells $\left(5 \times 10^{6}\right)$ were harvested by trypsin digestion at $48 \mathrm{~h}$ after transfection, centrifuged at $15000 \mathrm{~g}$ for $20 \mathrm{~min}$ at RT, and the supernatant was discarded. In the experiment examining chromosomal DNA fragmented by AChE polypeptide, HeLa cells $\left(2.5 \times 10^{7}\right)$ were harvested, fixed with $4 \%$ paraformaldehyde for $15 \mathrm{~min}$, permeabilized twice with $0.5 \%$ Triton X-100 (15 min per incubation) at RT, and then incubated with $21 \mu \mathrm{m}$ hAChET547 overnight at $37^{\circ} \mathrm{C}$. Subsequently, DNA was extracted using the phenol/chloroform method. The samples were subjected to $1.5 \%$ agarose gel electrophoresis, stained with ethidium bromide, and visualized using the Tanon 2500 gel imaging system.

\section{Immunofluorescence assays}

The assay was performed as described previously [3]. Briefly, cells grown on the coverslips in a 24-well plate were washed with $0.01 \mathrm{~m}$ phosphate-buffered saline $(153.8 \mathrm{~mm} \mathrm{NaCl}, 11.2 \mathrm{~mm}$ $\left.\mathrm{Na}_{2} \mathrm{HPO}_{4} .12 \mathrm{H}_{2} \mathrm{O}, 2.6 \mathrm{~mm} \mathrm{NaH} \mathrm{PO}_{4} .2 \mathrm{H}_{2} \mathrm{O}, \mathrm{pH} 7.2-7.4\right)$ and fixed with $4 \%$ paraformaldehyde for $15 \mathrm{~min}$ at RT. Following permeabilization in $0.5 \%$ Triton $\mathrm{X}-100$ for $10 \mathrm{~min}$, cells were washed three times with $0.01 \mathrm{~m}$ phosphate-buffered saline and then incubated with blocking buffer (5\% normal goat serum) for 20 min at RT. Cells were incubated with primary antibody at $4{ }^{\circ} \mathrm{C}$ overnight, washed three times and incubated with the secondary antibody for $30 \mathrm{~min}$ at $37^{\circ} \mathrm{C}$ in the dark, followed by $0.1 \mu \mathrm{g} / \mathrm{ml} \mathrm{4',6-diamidino-2-phenylindole} \mathrm{(Sigma-Aldrich)} \mathrm{stain-}$ ing at RT for $5 \mathrm{~min}$. The labeled cells were then washed, transferred onto glass slides, and observed under a laser scanning confocal microscope (Leica). The following primary antibodies were used: cleaved caspase-3 (Asp175) rabbit polyclonal antibody (Cell Signaling, Shanghai, China, \#9661, 1:100) and rabbit polyclonal anti-EndoG antibody (Abcam, Shanghai, China, ab9647, 1:100). The corresponding secondary antibodies were Cy3-AffiniPure goat anti-rabbit IgG (Jackson Immunoresearch Laboratories, West Grove, PA, USA, 111165-045, 1:500) and Alexa Fluor 647 goat anti-rabbit IgG (Molecular Probes, Eugene, Oregon, USA, A-21244, 1:500), respectively. The images were taken under a laser scanning confocal microscope (Leica, Wetzlar, Hessen, Germany).

\section{Congo red staining}

Congo red (Sigma-Aldrich) staining for $A \beta$ amyloid was performed as described previously [56].

\section{Statistical analysis}

Data were expressed as mean \pm s.d. The significance of differences between two groups was analyzed using two-tailed Student's $t$-tests. $P$-values $<0.05$ were considered to indicate statistical significance.

\section{Acknowledgements}

We are grateful to Dr Palmer Taylor (Department of Pharmacology, University of California) for presenting materials that made the study possible. We are grateful to Dr Lin Li (Institute of Biochemistry and Cell Biology, Shanghai Institutes for Biological Sciences, Chinese Academy of Sciences) for his guidance in this work. We are also grateful to Dr Dangsheng Li (Shanghai Information Center for Life Sciences, Shanghai Institutes for Biological Sciences, Chinese Academy of Sciences) for helpful discussions and suggestions in this work. The work was supported by the grants from the Science and Technology Commission of Shanghai Municipality (14ZR1446600). 


\section{References}

1 Meshorer E, Toiber D, Zurel D, et al. Combinatorial complexity of $5^{\prime}$ alternative acetylcholinesterase transcripts and protein products. $J$ Biol Chem 2004; 279: 29740-29751.

2 Grisaru D, Sternfeld M, Eldor A, Glick D, Soreq H. Structural roles of acetylcholinesterase variants in biology and pathology. Eur J Biochem 1999; 264: 672-686.

3 Xie J, Jiang $\mathrm{H}$, Wan $\mathrm{YH}$, et al. Induction of a $55 \mathrm{kDa}$ acetylcholinesterase protein during apoptosis and its negative regulation by the Akt pathway. J Mol Cell Biol 2011;3: 250-259.

4 Zhang XJ, Yang L, Zhao Q, et al. Induction of acetylcholinesterase expression during apoptosis in various cell types. Cell Death Differ 2002; 9: 790-800.

5 Jing $\mathrm{P}$, Jin QH, Wu J, Zhang XJ. GSK3 beta mediates the induced expression of synaptic acetylcholinesterase during apoptosis. J Neurochem 2008; 104: 409-419.

6 Ye WY, Gong XW, Xie J, et al. AChE deficiency or inhibition decreases apoptosis and $\mathrm{p} 53$ expression and protects renal function after ischemia/reperfusion. Apoptosis 2010; 15: 474-487.

7 Iglesias-Guimarais V, Gil-Guinon E, Sanchez-Osuna M, et al. Chromatin collapse during caspase-dependent apoptotic cell death requires DNA fragmentation factor, $40-\mathrm{kDa}$ subunit-/caspase-activated deoxyribonuclease-mediated 3'-OH single-strand DNA breaks. J Biol Chem 2013; 288: 9200-9215.

8 Polzar B, Zanotti S, Stephan H, et al. Distribution of deoxyribonuclease $\mathrm{I}$ in rat tissues and its correlation to cellular turnover and apoptosis (programmed cell death). Eur J Cell Biol 1994; 64: 200-210.

9 Rauch F, Polzar B, Stephan H, Zanotti S, Paddenberg R, Mannherz HG. Androgen ablation leads to an upregulation and intranuclear accumulation of deoxyribonuclease I in rat prostate epithelial cells paralleling their apoptotic elimination. J Cell Biol 1997; 137: 909-923.

10 Nakagawa A, Shi Y, Kage-Nakadai E, Mitani S, Xue D. Caspase-dependent conversion of Dicer ribonuclease into a death-promoting deoxyribonuclease. Science 2010; 328: 327-334.

11 Sakahira H, Enari M, Nagata S. Cleavage of CAD inhibitor in CAD activation and DNA degradation during apoptosis. Nature 1998; 391: 96-99.

12 Li LY, Luo X, Wang X. Endonuclease G is an apoptotic DNase when released from mitochondria. Nature 2001; 412: 95-99.

13 Gueroult M, Picot D, Abi-Ghanem J, Hartmann B, Baaden M. How cations can assist DNase I in DNA binding and hydrolysis. PLoS Comput Biol 2010; 6: e1001000.

14 Fischer H, Scherz J, Szabo S, et al. DNase 2 is the main DNA-degrading enzyme of the stratum corneum. PLoS One 2011; 6: e17581.

15 Lechardeur D, Dougaparsad S, Nemes C, Lukacs GL. Oligomerization state of the DNA fragmentation factor in normal and apoptotic cells. J Biol Chem 2005; 280: 40216-40225.
16 Korn C, Scholz SR, Gimadutdinow O, Lurz R, Pingoud A, Meiss G. Interaction of DNA fragmentation factor (DFF) with DNA reveals an unprecedented mechanism for nuclease inhibition and suggests that DFF can be activated in a DNA-bound state. $J$ Biol Chem 2005; 280: 6005-6015.

17 Kamada S, Kikkawa U, Tsujimoto Y, Hunter T. Nuclear translocation of caspase-3 is dependent on its proteolytic activation and recognition of a substrate-like protein(s). J Biol Chem 2005; 280: 857-860.

18 Parrish JZ, Yang C, Shen B, Xue D. CRN-1, a Caenorhabditis elegans FEN-1 homologue, cooperates with CPS-6/EndoG to promote apoptotic DNA degradation. EMBO J 2003; 22: 3451-3460.

19 Dvir H, Silman I, Harel M, Rosenberry TL, Sussman JL. Acetylcholinesterase: from 3D structure to function. Chem Biol Interact 2010; 187: 10-22.

20 Liu X, Li P, Widlak P, et al. The 40-kDa subunit of DNA fragmentation factor induces DNA fragmentation and chromatin condensation during apoptosis. Proc Natl Acad Sci USA 1998; 95: 8461-8466.

21 Widlak P, Li LY, Wang X, Garrard WT. Action of recombinant human apoptotic endonuclease $G$ on naked DNA and chromatin substrates: cooperation with exonuclease and DNase I. J Biol Chem 2001; 276: 48404-48409.

22 Nakamura M, Sakaki Y, Watanabe N, Takagi Y. Purification and characterization of the $\mathrm{Ca} 2+$ plus $\mathrm{Mg} 2$ +-dependent endodeoxyribonuclease from calf thymus chromatin. J Biochem 1981; 89: 143-152.

23 Widlak P, Li P, Wang X, Garrard WT. Cleavage preferences of the apoptotic endonuclease DFF40 (caspase-activated DNase or nuclease) on naked DNA and chromatin substrates. $J$ Biol Chem 2000; 275: 8226-8232.

24 Napirei M, Wulf S, Eulitz D, Mannherz HG, Kloeckl T. Comparative characterization of rat deoxyribonuclease 1 (Dnase1) and murine deoxyribonuclease 1-like 3 (Dnase113). Biochem J 2005; 389: 355-364.

25 Shiokawa D, Hirai M, Tanuma S. cDNA cloning of human DNase gamma: chromosomal localization of its gene and enzymatic properties of recombinant protein. Apoptosis 1998; 3: 89-95.

26 Liu X, Zou H, Slaughter C, Wang X. DFF, a heterodimeric protein that functions downstream of caspase-3 to trigger DNA fragmentation during apoptosis. Cell 1997; 89: $175-184$.

27 Samejima K, Earnshaw WC. Trashing the genome: the role of nucleases during apoptosis. Nat Rev Mol Cell Biol 2005; 6: 677-688.

28 Pisetsky DS, Gauley J, Ullal AJ. Microparticles as a source of extracellular DNA. Immunol Res 2011; 49: 227-234.

29 Hsiao YY, Nakagawa A, Shi Z, Mitani S, Xue D, Yuan HS. Crystal structure of CRN-4: implications for domain function in apoptotic DNA degradation. Mol Cell Biol 2009; 29: 448-457.

30 Parrish JZ, Xue D. Functional genomic analysis of apoptotic DNA degradation in C. elegans. Mol Cell 2003; 11: 987-996. 
31 Marchot P, Ravelli RB, Raves ML, et al. Soluble monomeric acetylcholinesterase from mouse: expression, purification, and crystallization in complex with fasciculin. Protein Sci 1996; 5: 672-679.

32 Bourne Y, Taylor P, Bougis PE, Marchot P. Crystal structure of mouse acetylcholinesterase. A peripheral siteoccluding loop in a tetrameric assembly. J Biol Chem 1999; 274: 2963-2970.

33 Toiber D, Greenberg DS, Soreq H. Pro-apoptotic proteinprotein interactions of the extended N-AChE terminus. J Neural Transm 2009; 116: 1435-1442.

34 Pipkorn R, Boenke C, Gehrke M, Hoffmann R. High-throughput peptide synthesis and peptide purification strategy at the low micromol-scale using the 96-well format. J Pept Res 2002; 59: 105-114.

35 Germann MW, Johnson CN, Spring AM. Recognition of damaged DNA: structure and dynamic markers. Med Res Rev 2012; 32: 659-683.

36 Widlak P, Garrard WT. Discovery, regulation, and action of the major apoptotic nucleases DFF40/CAD and endonuclease G. J Cell Biochem 2005; 94: 1078-1087.

37 Jin QH, He HY, Shi YF, Lu H, Zhang XJ. Overexpression of acetylcholinesterase inhibited cell proliferation and promoted apoptosis in NRK cells. Acta Pharmacol Sin 2004; 25: 1013-1021.

38 Lai HJ, Lo SJ, Kage-Nakadai E, Mitani S, Xue D. The roles and acting mechanism of Caenorhabditis elegans DNase II genes in apoptotic dna degradation and development. PLoS One 2009; 4: e7348.

39 Counis MF, Torriglia A. Acid DNases and their interest among apoptotic endonucleases. Biochimie 2006; 88: 1851-1858.

40 Park SE, Jeong SH, Yee SB, et al. Interactions of acetylcholinesterase with caveolin-1 and subsequently with cytochrome c are required for apoptosome formation. Carcinogenesis 2008; 29: 729-737.

41 Toiber D, Berson A, Greenberg D, Melamed-Book N, Diamant S, Soreq H. N-acetylcholinesterase-induced apoptosis in Alzheimer's disease. PLoS One 2008; 3: e3108.

42 Zhang B, Yang L, Yu LY, et al. Acetylcholinesterase is associated with apoptosis in beta-cells and contributes to IDDM pathogenesis. Acta Biochim Biophys Sin 2012; 44: 207-216.

43 Noh MY, Koh SH, Kim Y, Kim HY, Cho GW, Kim SH. Neuroprotective effects of donepezil through inhibition of GSK-3 activity in amyloid-beta-induced neuronal cell death. J Neurochem 2009; 108: 1116-1125.

44 Zhang $\mathrm{X}$, Lu L, Liu S, Ye W, Wu J, Zhang X. Acetylcholinesterase deficiency decreases apoptosis in dopaminergic neurons in the neurotoxin model of Parkinson's disease. Int J Biochem Cell Biol 2013; 45: 265-272.

45 Francis PT, Nordberg A, Arnold SE. A preclinical view of cholinesterase inhibitors in neuroprotection: do they provide more than symptomatic benefits in
Alzheimer's disease? Trends Pharmacol Sci 2005; 26: 104-111.

46 Zhou J, Fu Y, Tang XC. Huperzine A protects rat pheochromocytoma cells against oxygen-glucose deprivation. Neuroreport 2001; 12: 2073-2077.

47 Wang R, Zhou J, Tang XC. Tacrine attenuates hydrogen peroxide-induced apoptosis by regulating expression of apoptosis-related genes in rat PC12 cells. Mol Brain Res 2002; 107: 1-8.

48 Akasofu S, Kosasa T, Kimura M, Kubota A. Protective effect of donepezil in a primary culture of rat cortical neurons exposed to oxygen-glucose deprivation. Eur $J$ Pharmacol 2003; 472: 57-63.

49 Farchi N, Shoham S, Hochner B, Soreq H. Impaired hippocampal plasticity and errors in cognitive performance in mice with maladaptive AChE splice site selection. Eur $J$ Neurosci 2007; 25: 87-98.

50 Reilly JF, Games D, Rydel RE, et al. Amyloid deposition in the hippocampus and entorhinal cortex: quantitative analysis of a transgenic mouse model. Proc Natl Acad Sci USA 2003; 100: 4837-4842.

51 Cohen JE, Zimmerman G, Melamed-Book N, Friedman A, Dori A, Soreq H. Transgenic inactivation of acetylcholinesterase impairs homeostasis in mouse hippocampal granule cells. Hippocampus 2008; 18: 182-192.

52 Wei QX, Van Der Hoeven F, Hollstein M, Odell AF. Efficient introduction of specific TP53 mutations into mouse embryonic fibroblasts and embryonic stem cells. Nat Protoc 2012; 7: 1145-1160.

53 Nunez J. Primary culture of hippocampal neurons from P0 newborn rats. J Vis Exp 2008; 19: 895-896.

54 Radic Z, Pickering NA, Vellom DC, Camp S, Taylor P. Three distinct domains in the cholinesterase molecule confer selectivity for acetyl- and butyrylcholinesterase inhibitors. Biochemistry 1993; 32: 12074-12084.

55 Radic Z, Quinn DM, Vellom DC, Camp S, Taylor P. Allosteric control of acetylcholinesterase catalysis by fasciculin. J Biol Chem 1995; 270: 20391-20399.

56 Bacskai BJ, Hickey GA, Skoch J, et al. Fourdimensional multiphoton imaging of brain entry, amyloid binding, and clearance of an amyloid-beta ligand in transgenic mice. Proc Natl Acad Sci USA 2003; 100: $12462-12467$.

(Supplementary Information is linked to the online version of the paper on the Cell Discovery website.)

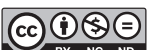

This work is licensed under a Creative Commons Attribution-NonCommercial-NoDerivs 4.0 International License. The images or other third party material in this article are included in the article's Creative Commons license, unless indicated otherwise in the credit line; if the material is not included under the Creative Commons license, users will need to obtain permission from the license holder to reproduce the material. To view a copy of this license, visit http:// creativecommons.org/licenses/by-nc-nd/4.0/ 